\title{
The contribution of bovines to human health against viral infections
}

\author{
AbdulRahman A. Saied $^{1,2}$ (1) $\cdot$ Asmaa A. Metwally $^{3}$ (1) $\cdot$ Hams M.A. Mohamed $^{4}$ (D) $\cdot$ Mohie A.M. Haridy $^{5}$ (I)
}

Received: 23 March 2021 / Accepted: 12 June 2021 / Published online: 16 July 2021

(C) The Author(s), under exclusive licence to Springer-Verlag GmbH Germany, part of Springer Nature 2021

\begin{abstract}
In the last 40 years, novel viruses have evolved at a much faster pace than other pathogens. Viral diseases pose a significant threat to public health around the world. Bovines have a longstanding history of significant contributions to human nutrition, agricultural, industrial purposes, medical research, drug and vaccine development, and livelihood. The life cycle, genomic structures, viral proteins, and pathophysiology of bovine viruses studied in vitro paved the way for understanding the human counterparts. Calf model has been used for testing vaccines against RSV, papillomavirus vaccines and anti-HCV agents were principally developed after using the BPV and BVDV model, respectively. Some bovine viruses-based vaccines (BPIV-3 and bovine rotaviruses) were successfully developed, clinically tried, and commercially produced. Cows, immunized with HIV envelope glycoprotein, produced effective broadly neutralizing antibodies in their serum and colostrum against HIV. Here, we have summarized a few examples of human viral infections for which the use of bovines has contributed to the acquisition of new knowledge to improve human health against viral infections covering the convergence between some human and bovine viruses and using bovines as disease models. Additionally, the production of vaccines and drugs, bovine-based products were covered, and the precautions in dealing with bovines and bovine-based materials.
\end{abstract}

Keywords Bovines · Bovine-based products · Contribution · COVID-19 $\cdot$ Human viruses · One medicine $\cdot$ Transchromosomic bovines

\section{Introduction}

Cattle belong to the Cetartiodactyla order of eutherian mammals, which is phylogenetically distinct from humans, the primates order (Murphy et al. 2004). Although cows aren't the closest animal to

Responsible Editor: Lotfi Aleya

AbdulRahman A. Saied

saied_abdelrahman@yahoo.com

Mohie A.M. Haridy

mohieharidy@svu.du.eg

1 Department of Food Establishments Licensing (Aswan Branch), National Food Safety Authority (NFSA), Aswan 81511, Egypt

2 Touristic Activities and Interior Offices Sector (Aswan Office), Ministry of Tourism and Antiquities, Aswan 81511, Egypt

3 Department of Surgery, Anesthesiology, and Radiology, Faculty of Veterinary Medicine, Aswan University, Aswan 81511, Egypt

4 Department of Microbiology, Faculty of Veterinary Medicine, South Valley University, Qena 83523, Egypt

5 Department of Pathology and Clinical Pathology, Faculty of Veterinary Medicine, South Valley University, Qena 83523, Egypt humans, human and cow DNA sequences are nearly identical (Zimin et al. 2009). Constructing a cattle-human comparative map using radiation hybrid $(\mathrm{RH})$ mapping, a genetic technique for mapping mammalian chromosomes, revealed approximately $91 \%$ of the comparative coverage of the human genome sequence (Everts-van der Wind et al. 2005).

Bovines have significant contributions to human foods, industry, livelihood, medical research, and pharmaceutical development. Although there are differences between humans and bovines, the similarities between them are not tiny such as, but not limited to, a) the same approximate gestation period of 280 days between bovine and human (Schultz et al. 1973); b) the similar timing of the immune system development and fetal placentation (Baldwin and Telfer 2015), c) bovines respond in the same way, to a large extent, as humans to the viral infections such as respiratory syncytial virus (RSV) (McCluskey 2003); d) the factors of disease outbreaks in bovine populations and human settings are very similar such as poor hygiene, crowding, a high rate of individuals turnover in the facility, contaminated fomites, close contact, and compromised skin integrity (Lanzas et al. 2010); e) bovines and humans share many similar pathogens such as coronaviruses, papillomaviruses, babesiosis, tuberculosis and brucellosis (Haydon et al. 2002). 
In the eighteenth century, the amazing work of Edward Jenner, the father of immunology, to vaccinate a boy with cowpox, as a prior infection, against smallpox rendered the boy immune to smallpox infection and paved the way for the vaccination in its current form (Kues and Niemann 2004). The development of the BCG vaccine (Waters et al. 2012), the tuberculin skin test and the interferon-gamma test (Wood et al. 1990), which were first introduced in cattle to prevent and diagnose bovine tuberculosis and later extended to humans, reflect the related accomplishments and discoveries in bovine and human immunology (Baldwin and Telfer 2015). Cattle and humans share various immune-physiological characteristics, including the in utero development of the immune system, which makes cattle an excellent model for human immunology (Baldwin and Telfer 2015). Unlike rodent models, cattle models have answers that improved our understanding of the immune system such as gamma delta $(\gamma \delta)$-T cells (Baldwin and Telfer 2015), but they also contributed to human health through beneficial clinical outcome (Hein and Griebel 2003). $\gamma \delta \mathrm{T}$ cells are a special type of T cells that is found in many peripheral tissues such as lungs, but is uncommon in secondary lymphoid organs (Ribot et al. 2020). Animal models are central in the production and testing of vaccines and therapeutic drugs (Colby et al. 2017) and laboratory animals are the main animal models for studying specific aspects of human pathogenesis and immunity, especially mice (Lanzas et al. 2010). However, for the pathogen under study, mice are more often surrogate model than natural model. Additionally, laboratory animals are commonly used as organism-level models, but not to fix population-level issues. Bovines are considered excellent candidates, coupled with mathematical models, for population-level studies of infectious disease dynamics (Lanzas et al. 2010), and that is attributed to that humans and bovines share pathogens (Woolhouse and Gowtage-Sequeria 2005), in addition, as bovines are natural reservoir hosts/natural animal model for some human pathogens (Cleaveland et al. 2001; Kues and Niemann 2004; Buddle et al. 2005; Lanzas et al. 2010; Bem et al. 2011). Their advantage lies in their very complexity, which mimics the biologically relevant situation (of human disease) (Wiles et al. 2006) in addition to, as previously mentioned, the similar factors of disease outbreaks. Therefore, bovine populations as farm animals are able to provide experimental models (Lanzas et al. 2010), which is suitable for explaining the transmission of human infectious agents at the population level, their disease pathogenesis and the triggered immune response. In addition, the biological information can be gained at the level of organ or tissue from biopsies and autopsies samples, which can be carried out easily and regularly (Lanzas et al. 2010).

The movements of infected animals are considered a crucial factor in spreading cattle diseases (Gilbert et al. 2005), such as Foot-and-mouth disease (Gibbens et al. 2001; Bouma et al. 2003; Ortiz-Pelaez et al. 2006; Martínez-López et al. 2008) and bovine virus diarrhea (Meyling et al. 1990; Gethmann et al. 2015). Cattle trade between cattle farmers occurs at a relatively high frequency creating a complicated network (Brzoska et al. 2020). Some European countries have built livestock movement databases, such as the Cattle Tracing System (CTS) data archive in Great Britain (England, Wales, and Scotland) (Gilbert et al. 2005), after bovine spongiform encephalopathy (BSE), commonly known as mad cow disease, investigations (Dubé et al. 2009). These data give richer information about pathogens dynamics and the benefits of these data exceed over than is typically available in wildlife or human systems (Lanzas et al. 2010).

To understand various diseases related to human health, bovines have been used as models for infectious (Hein and Griebel 2003; Lanzas et al. 2010) and non-infectious diseases, such as Niemann-Pick type C disease (Woolley et al. 2020). Cattle are one of the most used large animal models for acute respiratory distress syndrome (ARDS) (Ballard-Croft et al. 2012) and useful animal model for human respiratory pathogens such as Tuberculosis (Hewinson et al. 2003), Chlamydia psittaci infection (Reinhold et al. 2012; Ostermann et al. 2014), Human respiratory syncytial virus (Bem et al. 2011; Jordan et al. 2015), through studying pathophysiology and functional host-pathogen interactions in the mammalian lung and even developing immune-based approaches such as diagnostic tests and vaccines (Pollock et al. 2001, 2006), i.e., vaccines against human tuberculosis and RSV (Gershwin et al. 1998; Hewinson et al. 2003; Buddle et al. 2005; Taylor 2013; Gerdts et al. 2015). Cancer of the upper gastrointestinal tract in cattle (bovine papillomavirus (BPV)-4 and bracken fern) could act as models for the study of oncogenesis of papillomaviruses (Misdorp 1996), their molecular mechanisms (Cotchin 1962, 1976) and discovering novel therapeutics against (Misdorp 1996). The life cycle, genomic structures, viral proteins, and pathophysiology of bovine viruses studied in vitro paved the way for understanding the human counterparts such as Hepatitis $\mathrm{C}$ virus (HCV) that could not grow in cell culture (Buckwold et al. 2003).

Endemic stability is defined as the epidemiological condition of a population, despite high levels of infection in the population, clinical disease prevalence is low because immunity is acquired at a young age when the disease has milder manifestations (Coleman et al. 2001). Endemic stability has been developed previously to characterize tick-borne disease patterns in cattle (babesiosis and theileriosis in Australian and African cattle, respectively). Recently, the control procedures introduced for dengue virus (a viral disease spread by mosquitoes) were based on endemic stability (Egger et al. 2008).

Using oncolytic viruses for treating human cancers become one of the most interesting areas of research. Oncolytic bovine viruses such as Bovine herpesvirus type 1 (BHV-1) (Rodrigues et al. 2010), type 4 (BHV-4) (Farzani et al. 2021), and BVD (Marchica et al. 2020), could play a 
promising role in this trend due to their tropism, selective replication only in tumor cells, and possible synergic interaction with other therapeutics. Other significant contributions of bovines to human health (Kues and Niemann 2004; Redwan 2009) are using (A) bovine insulin for treating diabetes mellitus; (B) bovine glucagon to prevent hyperglycemia; (C) Aprotinin, a bovine protein-based drug, during complex surgery such as heart and liver surgery for reducing bleeding; (D) bovine heparin in the treatment of thrombotic conditions in both medical and surgical indications; (E) gelatin extracted from bovines, worldwide approved, in several pharmaceutical products such as vaccines and drugs; $(\mathrm{F})$ bovine hyaluronidase (Wydase $=$ Amphadase $)$ as an adjuvant (spreading agent) to increase the absorption and dispersion of the injected drug and (G) Pancreatin (food grade), commercial mixtures of amylase, lipase, and protease extracted from bovine pancreas, to treat malabsorption syndrome due to certain pancreatic problems (Redwan 2009).

Here we review some examples of human viruses and their bovine counterparts, elucidating the contribution of bovine virology and immunity to human virus research and human health in addition to the use of bovines as disease models (Table 1).

\section{DNA viruses in bovines and humans}

\section{Bovine and human papillomaviruses (BPV and HPV)}

BPV and HPV are members of the Papillomaviridae family, non-enveloped icosahedral structures, small circular ds DNA, $55-60 \mathrm{~nm}$ in diameter, 8000 base pairs, and are able to infect all vertebrates (Crawford and Crawford 1963; Campo 1988; Bernard et al. 2010). Their genome is made up of three different regions; long control region (LCR) or upstream regulatory region (URR) without ORFs, and the other two regions are responsible for encoding early (E1-E8 ORFs) and late (L1 and L2 ORFs) genes (Borzacchiello 2007; Alberti et al. 2010). Replication and transformation are regulated by the early genes (E1, E2, and E4). Capsid proteins are encoded by the two late genes (L1 and L2), and LCR has the origin of replication (ori) (Bogaert et al. 2007; Van Doorslaer 2013; Bocaneti et al. 2016) (Table 2). Expression of early and late genes occurs in epithelial cells in early maturation and differentiated keratinocytes, respectively.

Papillomaviruses (PVs) are one of the world's oldest viral families (Rector and Van Ranst 2013) that infect a wide range of hosts. They are originated in Africa then spread to all continents over one million years (Bernard 1994). Over 280 types of PV are categorized into 35 genera (de Villiers 2013; Rector and Van Ranst 2013). To date, roughly 170 types of HPV have been categorized and classified into five genera; Alpha, Beta, Gamma, Mu, and Nu-papillomavirus (Rector and Van Ranst 2013), and around 24 pathotypes of BPV have been described and categorized into four genera; Xi, Delta-, Epsilon, and Dyoxi-papillomavirus (Roperto et al. 2019). Although the actual numbers of HPV and BPV types may exceed 200 and 30, respectively. Most PV infections are asymptomatic without visible clinical signs. PVs are commonly found on the clinical normal skin of humans (Doorbar et al. 2012).

In 1981, Zur Hausen et al. explained that the etiologic agent of most cervical cancers is papillomavirus (zur Hausen et al. 1981). Cervical cancer is a serious malignancy that is considered the major cause of mortality among women (Bosch et al. 2002). Around 500,000 patients and 250,000 deaths globally occur per year with cervical cancer (Arbyn et al. 2011) and $85 \%$ of cervical cancer cases occur in developing countries where $75 \%$ of the world's population lives (Marrazzo and Holmes 2013). The HPV is suspected that is the possible etiologic agent of other human cancers as oropharyngeal, anal,
Table 1 Bovine contribution to the scientific research field

\begin{tabular}{ll}
\hline Human viruses & Contributions (Outputs) \\
\hline Human papillomavirus (HPV) & - Transformation \\
& - Latency mechanisms \\
Human lymphotropic T cell virus (HLTV-1) & - Vaccine development \\
Hepatitis virus C (HCV) & - Leukemogenesis \\
Human immunodeficiency virus (HIV) & - Antiviral drugs \\
Human parainfluenza virus 3 (HPI3) & - Antiviral drugs \\
Human rotaviruses & - Broadly neutralizing antibodies \\
Human respiratory syncytial virus (HRSV) & - Vaccine development \\
Human coronaviruses (HCoV) & - Vaccine development \\
& - Pathophysiology and immunobiology \\
& - Vaccine development \\
\hline
\end{tabular}


Table 2 Summary of PV proteins

\section{Replication proteins}

E1 - Recognition of origin of replication (ori).

- binds to E2 protein, resulting in E1-E2 complex.

- participates in the recruitment of host cell replication proteins.

- exhibits intrinsic ATPase/helicase activity.

E2 - Acts as E6 and E7 transcriptional regulator.

- participates in the maintenance of the viral genome in its episomal form by promoting binding between these genomes and mitotic chromosomes during cell division.

E4 - The most expressed protein of PVs and an important hallmark of PVs' pathogenic activity.

- occurs abundantly in the cytoplasm of the differentiated keratinocytes of papillomas.

- Unlike E1 \& E2, E4 is produced later in the differentiation process.

HPV16 E4 has also been associated with the collapse of cytokeratin filaments, which thus suggests an auxiliary function in the process of viral exit from cells.

\section{Oncoproteins}

E5 - Can induce both in vivo and in vitro transformation.

- The major BPV oncoprotein.

- Disrupt the Golgi complex leading to Inhibiting the expression of MHC-I and cyclooxygenase (COX). (An evolutionary mechanism of immune evasion).

- Bind to PDGFR ending with promoting cell cycle deregulation, stimulating angiogenesis.

- interferes with normal gap junctions.

- disturbs the actin cytoskeleton.

- increases the motility of transformed cells.

- Disrupting the cell cycle during a productive BPV infection.

These mechanisms contribute to viral infection persistence

- Most of the tumors of cattle affected by enzootic hematuria express BPV2 E5.

- HPV E5 has weak transforming activity, in contrast to its bovine counterpart, BPV1 E5, which shows strong transforming activity.

E6 - A small oncoprotein without enzymatic activity.

- Characterized by the presence of a class I PDZ domain, (found in BPV and high-risk HPVs).

- BPV and HPV E6 oncoprotein promotes p53 downregulation.

- Inducing cell transformation and immortalization due to the up-regulation of telomerases.

- BPV E6 protein binds paxillin, which correlates with its transformation function.

- prevents apoptosis by degrading p53.

- prolongs cell life by telomerase activation.

- binds to PDZ domains within several proteins involved in cell polarity, proliferation, and signaling.

E7 - binds to proteins of the retinoblastoma family (RB),

- regulate the expression of genes during the S-phase of the cell cycle.

- binds and degrades key regulators of cell cycling, including retinoblastoma protein (pRb), p107, and p130.

\section{Capsid proteins}

L1 - used in PVs virus classification into different types (able to self-organize in pentameric structures that compose the viral capsid).

- Allowing the capsid anchorage to heparin sulfate receptors present in the cell membrane.

- L1 immunodetection has been considered the main evidence of productive infection, (the virus assembly).

- C-terminal of L1 plays a cardinal part in BPV's infection and immunogenicity.

- produce VLPs that identical to that of intact viral particles.

- Strongly immunogenic inducing production of neutralizing antibodies.

L2 Component of the viral capsid.

Virus-like particles (VLPs) can be produced using prokaryotic and eukaryotic systems to express a combination of L1 and L2 or L1 alone

L3 A third structural protein (L3).

Present exclusively in BPV-4. However, its function remains unclear.

penile (Parkin 2006), lung, breast, bladder (Tolstov et al. 2014), and esophageal cancers (Dillner et al. 1995; Lagergren et al. 1999; Syrjänen 2002; Lyronis et al. 2005; Vieira et al. 2013). Therefore, it can be said that $30 \%$ of all human cancers are caused by HPV (Bravo et al. 2010). In 1982, Syrjänen was the first who explained that there is a relationship between HPV and esophageal cancer (Syrjänen 1982). Esophageal cancer is the world's sixth cancer that causes death (Antonsson et al. 2010; Herbster et al. 2012 ), and its mortality rate is $25 \%$ greater than that of cervical cancer (Han et al. 1996). 
Although majority of BPVs were detected in cutaneous papillomas hitherto (Daudt et al. 2018), BPV also causes esophageal, gastrointestinal, and bladder cancers. Death may be the inevitable end of these cancers (Borzacchiello and Roperto 2008; Kumar et al. 2015). In 1959, Olson, et al. (Olson et al. 1959) were able to induce urinary bladder cancer in calves by injecting bovine wart extracts. In 1992, it was reported that bladder cancers consistently developed in cattle that were fed bracken fern (Campo et al. 1992), leading to enzootic hematuria, and the role of E5 oncoprotein of BPV$1,2,13$, and 14 was detected in bladder cancers (Wosiacki et al. 2006; Balcos et al. 2008; Roperto et al. 2016; Russo et al. 2016). Consumption of bracken fern also predisposes the incidence of esophageal carcinoma (Masuda et al. 2011), which is directly associated with BPV-4 infection (Borzacchiello et al. 2003; Masuda et al. 2011). The clinical signs of esophageal carcinoma in humans (Felin et al. 2008; Haster and Owyang 2013) are similar to those in bovines (Borzacchiello et al. 2003). Immunosuppression is the most common identified cofactor for HPV-induced cancers (Chaturvedi et al. 2009). Also, BPV causes papillomas (Fig. 1) that can transform into cancers due to enhancing cofactors (biological, immunological, environmental, and genetic) (Roperto et al. 2008). These cofactors delay the infection clearance and subsequently promoting malignancy. Although PVs are speciesspecific, cross-species infection by BPV1 and 2 was recorded in equine species (Campo 2006), giraffe, sable antelope, buffaloes, and yaks (Pangty et al. 2010; Van Dyk et al. 2011; Bam et al. 2013). BPV-5, besides BPV-1, and -2, were found in ruminal wart-like lesions in buffaloes and cattle (Kumar et al. 2015). Feline sarcoid-associated papillomavirus DNA was also amplified from four bovine fibropapillomas and five inflammatory skin lesions that are homologous to BPV-2 with non-productive infection (Teifke et al. 2003; Munday and Knight 2010). All the previous cross-species infections by BPV confirm the hypothesis that cattle may be the natural host of feline sarcoid-associated papillomavirus (Munday and Knight 2010).

The similarities between BPV and HPV were reported based upon the phylogenetic analyses (García-Vallvé et al. 2005). BPV1 virion has a very similar structure to HPV1 (Baker et al. 1991). Unlike the two early proteins in HPV E6 and E7, E5 is expressed during BPV replication in cattle (Campos et al. 2013). The possibility of using HPV E6 and

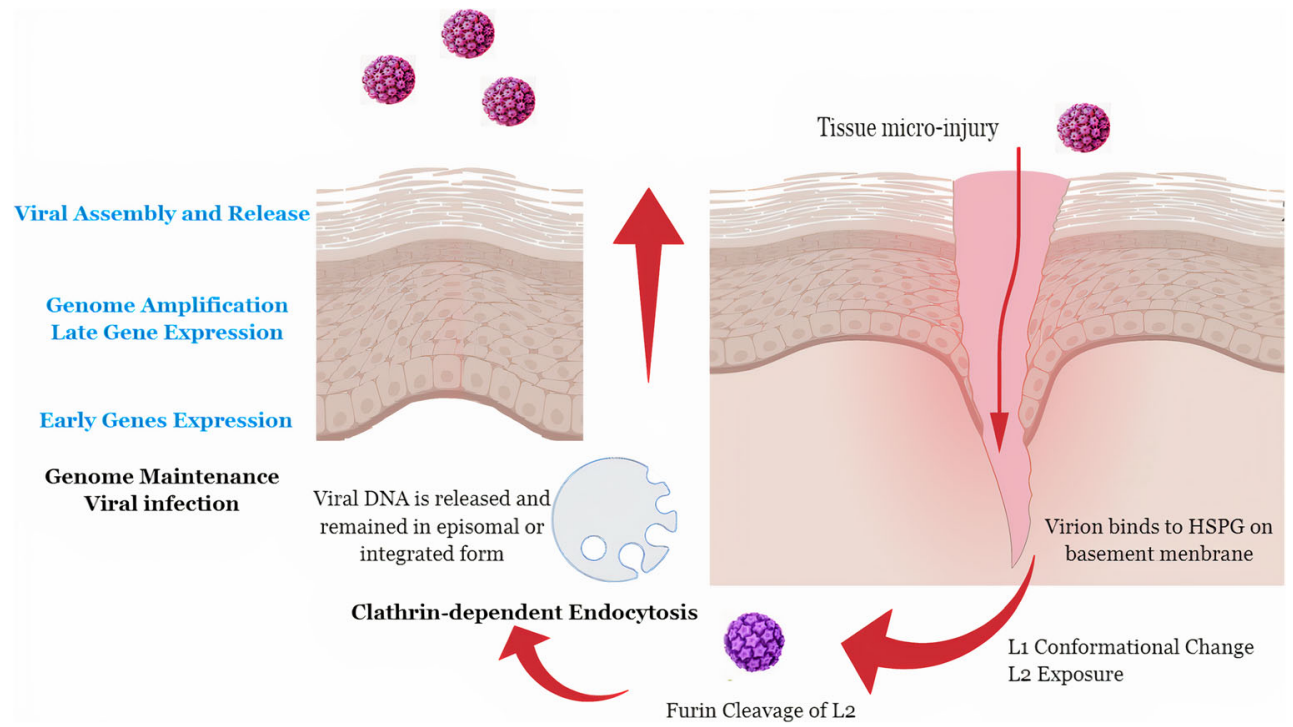

Fig. 1 Papillomavirus life cycle. Viral lodgment starts from tissue micro-injury (because these viruses cannot actively penetrate the skin of their host), but other routes were reported as infected lymphocytes (viral hematogenous infection to the skin or urinary bladder), infected semen, and infected milk. After tissue micro-injury, heparin sulfate proteoglycan (HSPG) receptors that present on the basement membrane (BM) provides access to the basal keratinocytes, are exposed to L1 binding leading to conformational changes in capsid icosahedral structure, exposing the L2 $\mathrm{N}$-terminal to be cleaved by extracellular furin protein that presents in the cell membrane inducing a second capsid conformational change, allowing L2 to bind to different receptors, such as integrin 24. Viral entry; virions internalization by clathrin-dependent endocytosis mechanism, resulting in cytoplasmic vesicles that associate to lysosomes, the lysosomal acid content release promotes $\mathrm{pH}$ alterations in capsid proteins, resulting in viral DNA release. BPV genome is found in episomal form and HPV genome can integrate into fragile sites of the host genome. Differentiation triggers the production of the PV early proteins that force the suprabasal cell to reenter the S-phase of the cell cycle resulting in cell cycle continuation. Amplification process: PVs induce the S-phase entry because they do not codify polymerase, stimulating cell proliferation, and inducing mitotic stress. As a result, many cell cycle checkpoints are abrogated. Consequently, an accumulation of mutations resulting in cytogenetic aberrations and progression into cancer occurs in cells that are persistently infected by these viruses. The productive infection occurs within the terminal differentiation and keratinization of an infected cell. PV late genes expression and viral assembly occur close to the cell surface and viral particles are released only after the epithelial cell sloughing from the epithelial surface and not by causing cell lysis. Thus, the viral life cycle is completed without directly causing cell death and without systemic viremia 
E7 in humans as a vaccine has been discussed (Borysiewicz et al. 1996; He et al. 2000; Yao et al. 2013), based on the therapeutic action of BPV E6 and E7 (Campo 1997). The single skin lesion in cattle could contain different BPV types (Claus et al. 2009; Carvalho et al. 2012; Kumar et al. 2013) as in human skin lesions, coinfection by different HPV types have been frequently detected (Antonsson et al. 2000). BPV plays a pivotal role as a model for HPV studies and vaccine development (Borzacchiello and Roperto 2008). Understanding the complicated interaction between HPV and human cancer has been shown by studies of BPV-associated lesions and BPV-infected cell lines. Based upon the ability of BPV to transform cells (Meischke 1979), it facilitates understanding the pathogenic mechanisms that lead to cancer (Araldi et al. 2016) and subsequent development of protective HPV vaccines and vaccine biotechnology (Munday 2014). Immunity to PV infection was principally studied using the BPV model (Dvoretzky et al. 1980), but developing a HPV vaccine followed the HPV16 and BPV1 L1 expression in insect cells (Zhou et al. 1991). The most important feature of L1 alone is having the intrinsic capacity for the assembly of virus-like particles (Kirnbauer et al. 1992). Not only for L1-based vaccine but also, L2-based vaccine demonstrated its protective effect in cattle, reinforcing the use of L2 in the future as a second vaccine against HPV infections (Lunardi et al. 2013), and may be used as a prophylactic and multivalent vaccine due to its cross-neutralizing epitope (Campo and Roden 2010).

Cervarix and Gardasil are the available prophylactic virus-like particles (VLP) vaccines against HPV with acceptable safety and tolerance (Ribeiro-Müller and Müller 2014). L1 VLP vaccine is a prophylactic vaccine and has no therapeutic effect in humans (Koutsky et al. 2002; Vandepapelière et al. 2005; Hildesheim et al. 2007). The immunity produced by L1 or L2 VLP-based vaccines can be mediated only by neutralizing antibodies (Gambhira et al. 2007; Day et al. 2008, 2010; Schiller et al. 2010) or with an extra contribution by $\mathrm{T}$ cell-mediated response (Jarrett et al. 1991). The disadvantages of PV vaccines are the limited protection for certain PV types and the high cost of production. An alternative way to yeast and insectcell is using Escherichia coli for expression of recombinant protein for vaccine production because $E$. coli do not require L1 VLP and is more stable (Ribeiro-Müller and Müller 2014). Another trend is using prostate cancer antigen, BPV VLP vaccines in transgenic adenocarcinoma of the mouse prostate (TRAMP), which showed safety and efficacy exceed over other vaccines. This vaccine is nominated to be used for patients in active-surveillance or patients with a high-risk of localized prostate cancer (Simons et al. 2020).

\section{RNA viruses in bovines and humans}

\section{Bovine leukemia virus (BLV) and human T cell leukemia virus type-1 (HTLV-1)}

A century passed between the discovery of bovine leukemia virus (BLV) and human T cell leukemia virus type 1 (HTLV1) (Leisering 1871; Gallo 2005). In 1979 and 1980, HTLV-1 was recovered from many people who suffered from adult $\mathrm{T}$ cell leukemia (ATL) (Poiesz et al. 1980a, b). HTLV-1 was established as the first retrovirus directly relevant to malignancy in humans (reviewed in (Matsuoka and Jeang 2007)). Worldwide, HTLV-1 infected 10-20 million people (Proietti et al. 2005), and it is endemic to some areas in Africa, Japan, and the Caribbean (Watanabe 2011).

Although enzootic bovine leukosis (EBL) was first reported in 1871 (Leisering 1871), most BLV infections in cattle are asymptomatic. Typical bovine leukemia has two forms; sporadic bovine leukosis and EBL (Gillet et al. 2007). The only route of BLV transmission is contact with infected cells through wet proboscis of insects because the free viral particles are unstable and inefficient in the infection phase (Cuesta et al. 2018). BLV-infected cattle are typically infected for life due to viral maintenance through clonal expansion of infected lymphocytes (Lezin et al. 2009). One of the common features of BLV-induced leukemogenesis is p53 mutation that occurs within the host genome and consequently, the essential p53 functions are disturbed (Ishiguro et al. 1997; Zhuang et al. 1997; Tajima et al. 1998). BLV may pass with a selfattenuating process to escape from immunosurveillance (Gillet et al. 2007) so, no direct detection of BLV viruses or proteins in peripheral blood (Lagarias and Radke 1989; Jensen et al. 1991).

Gag, pro, pol, and env are basic retrovirus genes (Fig. 2) that used to produce infectious virions and are flanked by two identical Long terminal repeats (LTRs) (Aida et al. 2013). The two identical LTRs are responsible for viral replication (Aida et al. 2013). The $\mathrm{pX}$ is a unique sequence present in both BLV and HTLV-1 genome between the env gene and 3' LTR. pX is neither a host cell nor an oncogene. In vitro immortalization of primary cells has been confirmed for both viruses (Grassmann et al. 1989; Willems et al. 1990). For both viruses, the surface unit (SU) and transmembrane unit (TM) proteins are encoded by env gene and their functions are accomplishing binding and attachment to cellular membrane receptors during viral entry (Lairmore 2014). Due to the common features in their structure, BLV and HTLV-1 viruses were grouped into a new single group (genus Deltaretrovirus) in the retroviruses family (Gillet et al. 2007). Both viruses share genomic similarities, routes of transmission, and similar pathogenesis (Lairmore 2014) (Fig. 3). In the $\mathrm{pX}$ region, two regulatory proteins, Tax and Rex, are encoded (Aida et al. 2013). The BLV pX region encodes R3 and G4 proteins and the HTLV-1 pX 

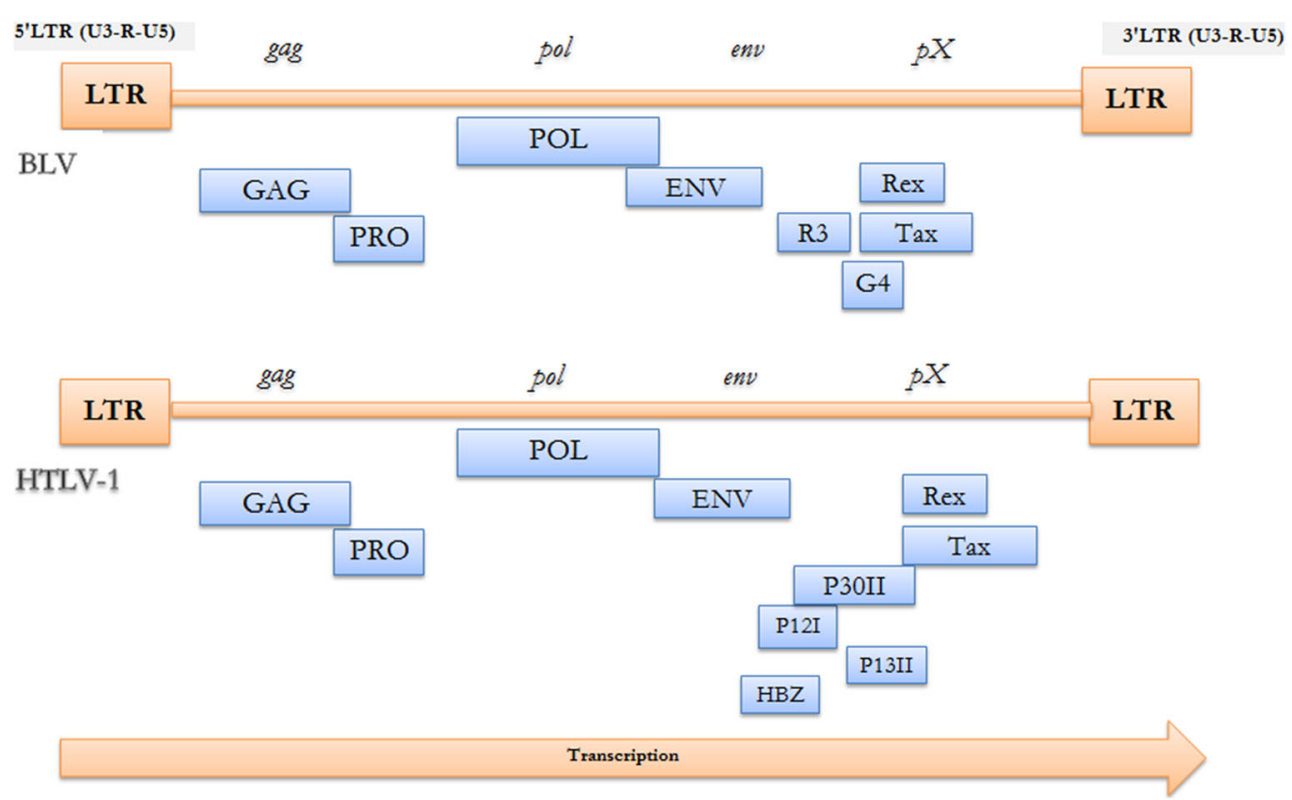

Fig. 2 Summary of BLV and HTLV-1 genes and their precursors and proteins produced (structural and enzymatic). Gene: Gag, Precursor: Pr44gag, Proteins: P15/MA (bind the genomic viral RNA interact with the lipid bilayer of the viral membrane - proteolytically processed to generate three fragments: $\mathrm{p} 10$, a seven amino acids product, and $\mathrm{p} 4$ ) - P12/NC (Tightly bind to the packaged genomic RNA) - P24/CA (The major constituent of the capsid (CA) of BLV virions - The major target for the host immune response). Gene: Pro (Prt), Precursor: pr66gag-prt, Proteins: p14/Prt (Protease). Gene: Pol, Precursor: Pr145, Proteins: P80/RT+IN (contains all of the tryptic peptides of the gagprotease precursor - encodes reverse transcriptase (RT), (RNA dependent DNA polymerase). Gene: Env, Precursor: Pr72env, Proteins: Gp51/SU (The extracellular SU is very immunogenic, a useful tool for diagnostics and vaccine development) - Gp30/TM (The TM transmembrane protein is a key factor in cell fusion during transmission and is involved in signal transduction via immunoreceptor tyrosine-based activation motifs (ITAM) present in the cytoplasmic tail). Gene: pX, Precursor: Tax ORF, Proteins: Tax (p34) (Transcriptional activator of viral expression -

region encodes p12I, p13II, and p30II (Sagata et al. 1984; Franchini et al. 2003). Unlike BLV genome, the HTLV-1 genome encodes a unique gene HBZ by the minus strand chain for basic leucine zipper factor (Gaudray et al. 2002), suggesting that the Tax protein has a crucial role in inducing the BLV leukemogenesis. In oncogenesis, the Tax protein affects the repair mechanisms for damaged DNA that contribute to an accumulation of mutations (Aida et al. 2013). So, BLV or HTLV-induced tumors take many years to appear after the first contact with these viruses.

Recently, Tax protein gained the attention of most researchers because of the belief in its key role in leukemogenesis for both BLV and HTLV-1 (Katoh et al. 1989; Tanaka et al. 1990; Willems et al. 1990). In addition, it is the key protein involved in viral replication (Aida et al. 2013). Tax is structurally distinguished by the presence of amino-terminal zinc finger and by a leucine-rich activation domain (Chen et al. 1989; Tajima and Aida 2000), and any alterations or substitutions entirely in them stop tax's transactivation target of the host immune response with $\mathrm{T}$ and $\mathrm{B}$ epitopes - Oncogenic potential - Activation of NF-kappa B (NF-KB) pathway - Inhibition of DNA repair of oxidative damage, increase accumulation of mutations in cellular DNA - Induction of DNA damage, cellular senescence and apoptosis - directly binds to tristetraprolin (TTP), a post-transcriptional modulator of TNF $\alpha$ expression - regulate many cellular proteins by direct binding) - Rex (p18) (Nuclear export of viral mRNAs - post-transcriptional regulation) - R3 (p5) (The maintenance of high viral load) - p12I (Maintenance of viral infectivity - Activation of nuclear factor of activated T cells (NFAT) pathway) - G4 (p11) like p13II (The maintenance of high viral load - Oncogenic potential) - p13II (Suppression of viral replication - Interaction with farnesyl pyrophosphate synthetase - Activation of Ras-mediated apoptosis) - p30II (Suppression of viral replication Regulation of gene transcription by binding with p300 - Enhancement of Myc transforming potential) - HBZ (Inhibition of HTLV-1 transcription - suppression of the classical pathway of NF- $\mathrm{kB}$ - Enhancement of TGF- $\beta$ signaling - Oncogenic potential)

activity. For both BLV and HTLV-1, the Tax gene is also highly conserved indicating the importance of the encoded Tax protein for virus replication and spread (Lairmore 2014). VLP were generated in mammalian cells by gag polyprotein overexpression (Callahan et al. 1976; Wang et al. 2004) providing a way to produce VLP-based vaccines similar to PVs vaccines.

The cross-reactivity between BLV and HTLV-1 capsid antigens (CA) is based on the common epitope BLV p24 (Morgan et al. 1983; Zandomeni et al. 1991), suggesting an evolutionary relationship between BLV and HTLV-1. BLV p24 and viral DNA were discovered in bovine mammary tissue, in which researchers have looked into the possibility of the presence of BLV in humans in the same tissue (Buehring et al. 1994). Also, an immune cross-reaction was found between the nucleocapsid (NC) proteins of BLV and feline leukemia virus (FeLV) (Morgan et al. 1983), suggesting that the bovine is the natural host of this virus (Lairmore 2014) and transmitted to human afterward. Viral expression in cultured 


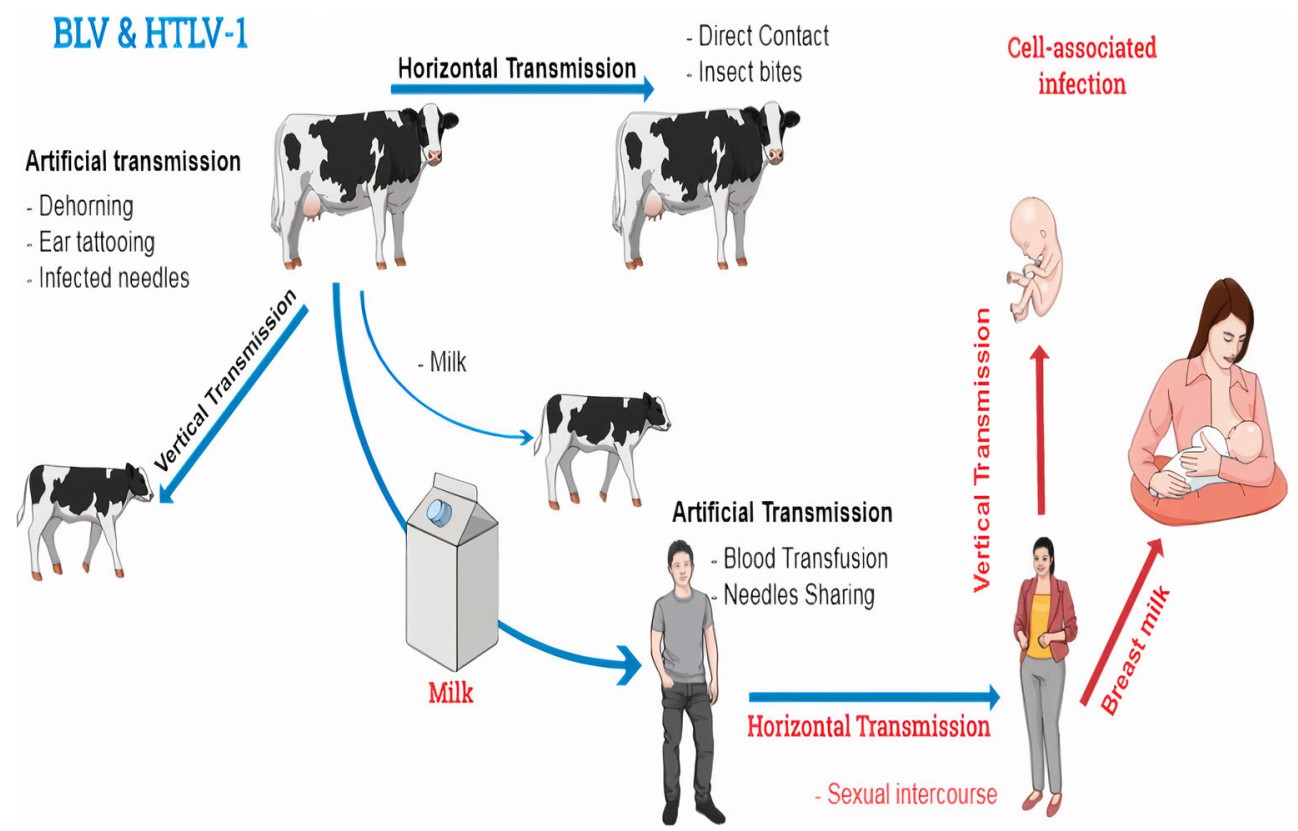

Fig. 3 BLV life cycle. BLV can be transmitted between bovines via horizontal and vertical transmission. Milk and insects play a role in BLV transmission. As well, HTLV-1 could be transmitted via horizontal and vertical transmission. Milk, sexual intercourse, and blood transfusion are routes of HTLV-1 transmission. Transfer of infected maternal lymphocytes to offspring is a natural transmission route of both BLV and HTLV-1. So, efficient transmission for both BLV and HTLV-1 requires cell-associated infection. The anti-BLV antibodies were clearly identified in the human serum. That is awakened the idea of a possible zoonotic

BLV-infected B-lymphocytes increased through deacetylation inhibition by histone deacetylase inhibitors in vitro (Achachi et al. 2005). This observation has served as a basis for increasing the virus-infected cells in HTLV-1 patients using histone deacetylase inhibitors to create targets for immune-mediated elimination. In vitro antibodies from some leukemic cattle can inhibit the reverse transcriptase activity (Gillet et al. 2007). Although nucleoside triphosphate analogs are potent inhibitors against human immunodeficiency virus reverse transcriptase (HIV-RT), they are ineffective against reverse transcriptase of BLV (Perach and Hizi 1999). The BLV model has also recently shed light on novel possibilities for HTLV-induced disease treatments (Gillet et al. 2007).

\section{Bovine viral diarrhea virus (BVDV) and hepatitis C virus (HCV)}

HCV is the world's most common cause of chronic hepatitis that progresses to end-stage liver diseases, such as cirrhosis and carcinoma (Liang et al. 2000). HCV is a Flaviviridae virus that belongs to the genus Hepacivirus. It was first identified in 1989 (Choo et al. 1990; Houghton 2009). Although $\mathrm{HCV}$ infection is often asymptomatic, it is estimated that 150 million chronic HCV infections, and over 350,000 deaths each year from $\mathrm{HCV}$-associated liver disease (Choo et al. 1990; Liang et al. 2000; Houghton 2009). It is worth disease. BLV might be transmitted to humans through unpasteurized milk or undercooked meat when bovine products were uncontrolled. Then, BLV had transmitted from person to person, like HTLV in body fluids once the virus was integrated into the human host genome. Both BLV and HTLV-1 infections are prevalent throughout the world. BLV was isolated from breast tissues. Designing eradication plans and improving preventive strategies are mandatory when the link between BLV and breast cancer is confirmed

mentioning that numbers of $\mathrm{HCV}$ infections increase by millions every year worldwide (Mohd Hanafiah et al. 2013). So, the need for finding a therapy for HCV is most urgent than a vaccine. Most patients in developing countries are devoid of new medicines, and safe vaccines are still not available (Drummer 2014; Pawlotsky 2014). BVDV belongs to the genus Pestivirus from the Flaviviridae family. Many clinical diseases in bovine species are caused by BVDV including respiratory, digestive, and reproductive manifestations (Baker 1995). Cytopathogenic and non-cytopathogenic biotypes of BVDV were identified based on their impact on host cells (Mendez et al. 1998).

BVDV and HCV are small, enveloped, positive-stranded RNA viruses encoding a single polyprotein precursor that is subsequently translated into ten different proteins by proteases from both the host and the virus. All proteins are encoded in a single, long ORF flanked by $5^{\prime}$ and $3^{\prime}$ untranslated regions with the structural proteins in the N-terminal end and the nonstructural proteins at the C-terminal end (Poole et al. 1995; Popescu et al. 2011). The $5^{\prime}$ terminus of the BVDV genome is not capped as in the HCV genome, and the start of translation is regulated by an internal ribosomal entry site (Poole et al. 1995). In the region encoding for the two heterodimerforming envelope proteins gp25 (E1) and gp53 (E2) of BVDV polyprotein, there are six potential N-glycosylation 
sites and in the region encoding for gp48 (E0) (a hydrophilic secreted protein of unknown function), there are eight potential N-glycosylation sites (Zitzmann et al. 1999).

BVDV utilizes the low-density lipoprotein (LDL) receptor to enter cells like HCV. Both viruses use a functionally identical internal ribosome entry site (IRES) for translation and an NS4A cofactor with its homologous NS3 serine protease. Both have a similar NS3 helicase/NTPase, a mechanistically similar NS5B RNA-dependent RNA polymerase, and a seemingly equivalent mechanism of virion maturation, assembly and egress (Buckwold et al. 2003).

Due to the high degree of similarity (Isken et al. 2007), BVDV has been most widely used in vitro as a surrogate model for understanding HCV replication (Weiskircher et al. 2009) and the discovery and development of anti-HCV agents because $\mathrm{HCV}$ does not replicate efficiently in cell cultures (Henzler and Kaiser 1998; Bhattacharyya et al. 2003; Buckwold et al. 2003; Yanagida et al. 2004; Romero et al. 2006; Zhang et al. 2010). To date, no HCV vaccine is available. Of the anti-HCV drugs, Interferon (IFN) and Ribavirin are available, but a combination of both is an expensive therapy and also induces several side effects (Bhattacharyya et al. 2003; Yanagida et al. 2004). The nonstructural protein 5B (NS5B) of BVDV has been formally validated as a target for antiviral drug discovery against HCV (De Clercq 2007). Consequently, HCV NS5B RNA-dependent RNA-polymerase (RdRp) is currently the most studied and used as a target for developing safe anti-HCV drugs. HCV NS5B RdRp is attractive for drug discovery due to its vital role in viral replication and the lack of RdRps in humans (Baginski et al. 2000; Paeshuyse et al. 2006; Puerstinger et al. 2007). The HCV p7 protein is necessary for $\mathrm{HCV}$ infectivity (Sakai et al. 2003) and is considered a pivotal target for anti-HCV therapy. Long-alkyl-chain iminosugar derivatives with antiviral activity against BVDV could inhibit the ion channel role of the $\mathrm{p} 7$ protein (Pavlović et al. 2003). Similarly, the small molecule BIT225 inhibits BVDV in vitro (Luscombe et al. 2010). 2'-C-methyl-cytidine showed an inhibitory activity against BVDV, and later showed to inhibit HCV RNA replication in the replicon assay (De Francesco and Migliaccio 2005). NM-283 (Valopicitabine) is an oral prodrug of 2'-C-methyl-cytidine, was synthesized for obtaining a molecule with higher oral bioavailability than its parent molecule, 20C-methyl-cytidine (Pierra et al. 2006). NM-283 is now being evaluated in phase II clinical trials for the treatment of chronic HCV infection (Tian et al. 2021).

BVDV, as a non-human pathogen virus, can interact with human CD46 and can cause apoptosis to human myeloma cells showing its specific oncolytic activity for multiple myeloma (MM) cells and is a possible alternative to the human viruses, such as measles virus and adenovirus, for an oncolytic approach in MM treatment (Marchica et al. 2020).
Discovery of novel HCV-like viruses in many hosts began after 2011, indicating the widespread of Hepaciviruses (Kapoor et al. 2011; Baechlein et al. 2015; Scheel et al. 2015; Hartlage et al. 2016). In 2015, Ghana and Germany reported the first cases of bovine Hepacivirus (BovHepV) (Baechlein et al. 2015; Corman et al. 2015). BovHepV is a hepatotropic virus such as HCV without an obvious zoonotic risk (Baechlein et al. 2015). Establishment of BovHepV as a novel HCV model (Baechlein et al. 2015) is based on the chronicity and high viral loads in the liver of infected cattle. More interest is demanded in investigating the zoonotic potential of BovHepV and its impact on human health (Baechlein et al. 2015).

\section{Bovine and human immunodeficiency viruses (BIV and HIV)}

HIV was discovered in 1983. It was identified as the cause of acquired immunodeficiency syndrome (AIDS) after being isolated (Barré-Sinoussi et al. 1983; Gallo et al. 1983). After a period of the belief that the human oncovirus HTLV-III was the causative virus of AIDS (Popovic et al. 1984), it was eventually renamed HIV-1 and taxonomically separated from HTLV. HIV killed over than 35 million since epidemic (Vemuri et al. 2020).

In 1969 during research on bovine leukosis in Louisiana, USA, bovine immunodeficiency virus (BIV), first designated bovine visna-like virus, was accidentally detected and isolated from infected Holstein cow (Van Der Maaten et al. 1972). BIV is a member of the lentivirus genus, subfamily Orthoretrovirinae from the Retroviridae family (King et al. 2011). BIV triggers a chronic infection in buffalo and cattle. BIV does not cause a specific disease, but it may cause immunosuppression in calves (Zhang et al. 1997). BIV infects the immune system cells mainly, monocytes/macrophages and lymphocytes (Gonda et al. 1987).

BIV is morphologically, genetically, and antigenically closely related to HIV-1 (Gonda et al. 1987). BIV R-29 isolate was demonstrated that it is very similar to HIV (Gonda et al. 1985, 1986, 1987). Both BIV and HIV-1 genomes contain the structural genes gag, pol, env, and several accessory genes, including tat, rev, vif, vpw, vpy, and tmx (Avidan et al. 2006). The genes vif, Tat, gag, pol, and env, of BIV and HIV-1 have some sequence similarity (Bhatia et al. 2013). BIV causes chronic inflammatory disease compared to HIV-1 that causes severe immunodeficiency (Bhatia et al. 2013). Moreover, in certain cases, BIV may be used as a surrogate animal model for HIV research (Bhatia et al. 2013).

Calves experimentally infected with BIV R-29 isolates displayed intermittent lymphocytosis and lymphadenopathy without any obvious clinical indications (Carpenter et al. 1992; Onuma et al. 1992; Suarez et al. 1993). Virus-specific antibodies found in calves against BIV R-29 strain (Whetstone et al. 1990) were primarily to $\mathrm{p} 26$, which is the most immunodominant 
protein of BIV (Abed et al. 1999). Also, cattle infected with BLV produced antibodies that can inhibit HIV-1 reverse transcriptase activity in vitro (Gillet et al. 2007).

Advances in understanding the viral life cycle are focused on endeavors to discover and develop anti-HIV drugs (De Clercq 2007). The key activator of viral gene expression is the Tat protein, which mediates a strong induction of the development of all viral transcripts by binding specifically to its cognate site, the transactivator response factor (TAR). Previous research on BIV Tat peptidomimetics contributed to the discovery of BIV2, a highly effective BIV Tat-TAR inhibitor. Using NMR techniques, the structure of BIV2 complex with BIV TAR was determined. Furthermore, the BIV Tat-TAR interaction was used as a model in discovering related peptidomimetic inhibitors of the Tat-TAR interaction in HIV-1 via exploiting the important information about RNA recognition, derived from the BIV Tat-TAR interaction (Athanassiou et al. 2007).

Since they can deliver the new gene by infecting the cell, viruses are often used as vectors. When used in humans, the viruses have been modified so that they do not cause disease. Vectors derived from BIV are an appealing alternative to those derived from HIV-1 (Matukonis et al. 2002) as virusbased gene transfer system.

Recombinant virus-like particles (VLPs) have been developed as a safe substitute to live or inactivated viruses for immunological, virological, and vaccine studies such as influenza virus-like particles (Bright et al. 2007; Pushko et al. 2007; Quan et al. 2010; Lua et al. 2014). Influenza VLPs comprised of hemagglutinin (HA), neuraminidase (NA), and matrix (M1) proteins. The gag of BIV (Bgag), in place of M1, can be used to prepare VLPs for several influenza subtypes (Tretyakova et al. 2016). Quadrisubtype H5/H7/H9/H10 VLPs were prepared using Bgag, which may be used as a first line of defense in the event of an outbreak involving $\mathrm{H} 5, \mathrm{H} 7, \mathrm{H} 9$, or $\mathrm{H} 10$ avian influenza viruses while a new vaccine against the culprit virus is being developed (Tretyakova et al. 2016).

Interestingly, Cows were immunized with HIV env produced potent broad neutralizing antibodies with long heavy-chain complementarity-determining region 3 (HCDR3), which can easily attack the CD4-binding site (CD4bs) on the Env trimer, but the situation in humans is different. Also, the pace of developing a broadly neutralizing antibody (bnAb) to the CD4bs of HIV Env in cows is noteworthy when compared with the length of time taken to generate equivalent antibodies in humans by natural infection (over five years) (Sok et al. 2017).

\section{Bovine and human parainfluenza viruses 3 (BPIV-3 and HPIV-3)}

HPIV-3 is the etiologic agent of lower respiratory tract diseases. It belongs to genus the Respirovirus from the Retroviridae family and is closely related to BPIV-3
(Welliver et al. 1986). Currently, no vaccine or drug was developed for the treatment of HPIV-3 (Hall 2001; Durbin and Karron 2003; Bartlett et al. 2007). BPIV-3 is one of the reasons for bovine respiratory disease complex (BRDC) (Snowder et al. 2006), whose immunosuppressive action results in severe bronchopneumonia due to bacterial co-infection, especially in stressed animals (Haanes et al. 1997). BPIV-3 belongs to genus the Respirovirus of Paramyxoviridae family (Adams et al. 2016). Approximately $25 \%$ of both viruses are antigenically related by cross-neutralization (van Wyke Coelingh et al. 1988). The hemagglutinin-neuraminidase $(\mathrm{HN})$ and fusion $(\mathrm{F})$ proteins of BPIV-3 and HPIV-3 share more than $75 \%$ of their amino acid sequences. (Bailly et al. 2000), and the two viruses share at least five neutralization epitopes on the $\mathrm{HN}$ and $\mathrm{F}$ proteins (Coelingh et al. 1986; Klippmark et al. 1990). Furthermore, between BPIV-3 and HPIV-3, the major viral nonglycoproteins $\mathrm{N}, \mathrm{M}$, and $\mathrm{L}$ are greater than $85 \%$ related (Pennathur et al. 2003).

Attenuated BPIV3 is utilized as a virus vector backbone to produce a safe, effective RSV vaccine (Haller et al. 2003). BPIV-3 is used to enhance both humoral and cellular immunity as a live virus vaccine in human beings against HPIV-3 disease based on the similarity between the two viruses. Neutralizing antibodies against $\mathrm{HN}$ and $\mathrm{F}$ play a key role in resistance to HPIV-3. In phase 2 clinical trials, a liveattenuated BPIV-3 vaccine was intranasally administered simultaneously with other routine vaccines (Greenberg et al. 1999; Lee et al. 2001) to infants aged 2, 4, and 6 months, a booster immunization at $12-15$ months of age showed safety and well tolerance of BPIV-3 in infants.

In human clinical studies, another live-attenuated HPIV-3 vaccine candidate was developed by reverse genetics that yielded a recombinant BPIV-3 (rBPIV-3), phenotypically similar to the bioderived BPIV-3 (Haller et al. 2000, 2001). Furthermore, the growth in serum-free (SF) Vero cells of BPIV-3, r-BPIV-3, or B/HPIV-3, chimeric bovine/human parainfluenza virus type 3 , did not affect vaccine yield, viral replication, immunogenicity, or efficacy in primates (Pennathur et al. 2003).

\section{Bovine and human rotaviruses (BRV \& HRV)}

In 1969, rotavirus (RV) had been discovered in diarrheic cattle (Mebus et al. 1969). Rotavirus multiplies in the intestinal epithelium leading to malabsorption, which causes severe diarrhea and toxemia (Organization 2009). Rotaviral diarrheas are common in calves and could cause death due to severe dehydration or secondary bacterial infections (Holland 1990; Saif 1990; Chauhan and Singh 1996). BRV is considered economically important and zoonotic pathogens (Parashar et al. 2006). In 1973, RVs were first identified as a significant cause of acute gastroenteritis in babies and young children (Bishop et al. 1973; Flewett et al. 
1973). Every year, RV cause around one hundred million cases of hospitalizations and deaths of children less than 5 years of age worldwide (Parashar et al. 2003, 2006).

Developing countries are likely to have the largest share of $\mathrm{RV}$-caused deaths for socioeconomic and epidemiological reasons (Angel et al. 2007). Rotavirus-specific serum IgA levels typically correlate with intestinal IgA levels following natural infection in children (Franco et al. 2006), and rotavirus $\mathrm{T}$ cell responses are associated with the development of protective antibodies (Offit et al. 1993).

Rotaviruses are a member of the Reoviridae family, which is an 11-segment, double-stranded RNA genome with nonenveloped, icosahedral symmetry (Estes and Cohen 1989; Pesavento et al. 2006). Six structural proteins are present, which constitute three concentric layers. The viral genome is surrounded by the inner layer and contains the scaffolding protein VP2, the RNA-dependent RNA polymerase VP1 and VP3 (a guanylyl transferase and methylase). The intermediate layer, which is a major structural protein, is made of VP6. The neutralizing antibodies are the targets of two virus surface proteins, VP4 and VP7, and either antibody can mediate defense. Six nonstructural proteins (NSP1-6) are formed in infected cells. Once VP4 is cleaved by intestinal trypsin, $\mathrm{VP}^{*}$ and $\mathrm{VP}^{*}$ are formed (an asterisk is to denote post-translational product), and interact with cellular receptors inducing infection.

Gene reassortment occurs at high frequency when two rotaviruses co-infect the same cell producing progeny viruses with mixed genes from both parental strains (Greenberg et al. 1981), with evidence for the zoonotic potential of animal rotaviruses to humans, leading either to a reassortment between animal and human rotaviruses circulating in humans (Gentsch et al. 2005) or causing disease (Martella et al. 2006; Matthijnssens et al. 2006). The generation of RV group A genomic diversity principally is caused by the reassortment (Estes and Greenberg 2013). The same evolutionary origin was proposed for bovine strains A5-10 and A5-13, and human DS-1-like strains (Komoto et al. 2016). Reassortment events between bovine and human RV group A strains may have produced the bovine strains A5-10 and A5-13 (Komoto et al. 2016).

In addition, rotaviruses generally exhibit substantial hostrange restriction (HRR), in which most human rotaviruses are highly attenuated in 'heterologous' animal hosts and vice versa (Angel et al. 2007). Based on gene reassortment and HRR, RotaShield and RotaTeq vaccines were developed (Angel et al. 2007). Both vaccines have been licensed in many countries.

RotaTeq vaccine has been designed to contain various serotypes to which a child could be exposed. It is a pentavalent vaccine consisting of five rotavirus strains, which are all derived from a parental WC3 bovine rotavirus strain and carry a gene from rotaviruses of human origin (a gene encoding VP4 or VP7) (Perez-Schael et al. 1997; Vesikari et al. 2006). The WC3 bovine virus grows well in vitro, but in contrast to Rotarix, the human rotavirus, is excreted by less than $6 \%$ of children (Vesikari et al.
2006). Induction of neutralizing serotype-specific antibodies was the gold standard for measuring immunogenicity to the RotaTeq vaccine (Clark et al. 2006).

\section{Bovine and human respiratory syncytial viruses (BRSV and HRSV)}

In 1970, BRSV disease was described in cattle for the first time (Paccaud and Jacquier 1970). BRSV causes a major respiratory disease in young calves resulting from seasonal outbreaks globally (Valarcher and Taylor 2007; Gershwin 2007). Cattle could be infected with HRSV (Thomas et al. 1984). In most veterinary researches, BRSV has been discussed in the context of bovine respiratory disease rather than from a human-centered perspective (Bem et al. 2011).

HRSV is considered an important cause of respiratory tract disease in humans (Ruuskanen and Ogra 1993). HRSV causes community outbreaks due to its stable transmission all the year-round reaching the peak during the winter months (Yusuf et al. 2007). The disease affects children under six months of age, frequently leads to hospitalization, often in intensive care for mechanical ventilation (Everard and Milner 1992), or causes the death of neonates and children in the presence of risk factors such as congenital heart defects and asthma. Also, more than 33 million infections, more than 3 million hospitalizations, and almost 200,000 deaths are in children under the age of 5 years per year (Nair et al. 2010). Not only children, but the elderly and adults could also be infected with HRSV (Falsey et al. 2005). HRSV infection in children is an immunologic process (interaction between the virus and the serum antibody). So, vaccine-induced serum antibody without local respiratory antibody does not protect against HRSV illness (Kim et al. 1969).

BRSV and HRSV are members of the genus Pneumovirus, the family Paramyxoviridae, are enveloped viruses with a negative-sense, non-segmented RNA genome and a length of 15,000 nucleotides. Virions have the same structure as each other, consisting of a nucleocapsid enclosed in a lipid envelope. The viral genome encodes eight structural proteins; the surface glycoproteins $\mathrm{G}$, the fusion proteins $\mathrm{F}$, the small hydrophobic SH protein (three viral transmembrane proteins), the nucleoprotein $\mathrm{N}$, the phosphoprotein $\mathrm{P}$, the transcription processivity factor M2-1, and the large polymerase subunit $\mathrm{L}$ (four nucleocapsids/polymerase proteins), and the matrix protein that presents on the inner face of the envelope (M). Two unique nonstructural proteins (NS1 and NS2) are present in high levels in infected cells (Easton et al. 2004). SH protein acts as a strong antiapoptotic protein and the function of $\mathrm{G}$ and $\mathrm{F}$ proteins is the binding and entry of HRSV and BRSV (Fuentes et al. 2007) into the host cell. Both viruses are genetically and antigenically closely related. Bovines play a dual role in HRSV researches as an animal model or alternative animal pneumovirus model, i.e., BRSV (Bem et al. 2011). 
Animal models are heavily used in the search for new medicines and vaccines for HRSV disease, in vivo pathophysiological and preclinical efficacy tests for potential therapies and vaccines. Animals are a significant link between studies of tissue culture and human phase I trials (Bem et al. 2011). Due to ethical and practical reasons besides, the scare in autopsy and biopsy findings with severe HRSV disease in humans make our knowledge about pathogenesis in humans is minimal. BRSV in calves could be used as a model to study the pathogenesis and immunity of RSV because calves are large animals allowing screening of the immune response by body fluids' collection and analysis of mucosal immune responses. Vaccines against RSV are available in cattle but not in humans till now (Meyer et al. 2008). To date, no HRSV vaccine is available for infants because of the absence of an animal model, the need for immunization of young infants, the risks in use of live vaccines, and the risk of vaccine-associated disease (Meyer et al. 2008). The subunit vaccines were yielded after intensive research on the HRSV vaccine which has been evaluated in animal models, such as calves (Blodörn et al. 2014; Taylor et al. 2014), and under clinical trials in humans (Green et al. 2015; Taylor et al. 2015; August et al. 2017; Beran et al. 2018). Studies conducted on laboratory animals generally, not refer to or extend to humans and cattle (Siegrist 2001; Rudd et al. 2005; Murawski et al. 2009; Willcocks et al. 2013). The RSV vaccines seemed to be efficacious in rodents, but they have not worked in humans (Guzman and Taylor 2015).

In contrast to infection that occurs without prior vaccination, vaccine-enhanced disease (VED) occurs when a person who has received a vaccine develops a more severe type of the disease when exposed to the virus afterward. VED phenomenon is also reported with other viruses (Huisman et al. 2009) such as measles and SARS-CoV-1.

In the 1960s, vaccination trials of children with formalininactivated RSV (FI-RSV) vaccine not only elicit protection against RSV infection but also provoke enhanced morbidity and mortality in vaccines (Knudson et al. 2015) and termed as enhanced respiratory syncytial virus disease (ERD). Surprisingly, $\sim 80 \%$ of the vaccinated children experienced serious disease and were hospitalized after acquiring a natural RSV infection, as compared to only $\sim 5 \%$ of a control group (Fulginiti et al. 1969; Kapikian et al. 1969; Belshe et al. 1982). RSV infection in children who have previously received a FIRSV vaccine is linked to increased disease and pulmonary eosinophilia, which is thought to be caused by an overactive memory Th2 response (Castilow et al. 2007). To date, no only single mechanism is responsible for VED, the potential mechanisms involved in this phenomenon are humoral ADE, cellular CD4 activation, DC/trans, and aberrant T-cell response (reviewed in (Huisman et al. 2009)).

The same scenario that occurred in calves when vaccinated with FI-BRSV vaccine showed that the vaccine-induced disease phenomenon is due to enhancing a Th2 mediated immune response (Gershwin et al. 1998; Kalina et al. 2004). So, calf vaccinated with FI-BRSV vaccine was used as a model of vaccine enhanced respiratory syncytial virus pathophysiology (Gershwin et al. 1998) in children. This model enabled researchers to produce RSV vaccines besides understanding RSV immunobiology (Gershwin et al. 1998). The innate immune response in calves is activated by RSV infection, which results in the production of pro-inflammatory cytokines and chemokines (Das et al. 2005; Valarcher and Taylor 2007; Sacco et al. 2012; Gershwin 2012). BRSV- and HRSVinfected macrophages and epithelial cells produce Interleukin 1 beta (IL-1 $\beta$ ) (Werling et al. 2002; BermejoMartin et al. 2008; Fach et al. 2010; Taylor et al. 2014), which orchestrates the pro-inflammatory response enhancing interferon-gamma (IFN $\gamma$ ) production.

RSV infection is detected by various pattern recognition receptors (PRR) such as RIG-I receptors, Toll-like receptors (TLR), and nucleotide oligomerization domain (NOD)-like receptors, inducing the production of type I IFN that in turn have antiviral effects on neighboring non-infected cells (Saminathan et al. 2019). RSV, on the other hand, is more resistant to type I IFN's antiviral effects than other paramyxoviruses (Atreya and Kulkarni 1999; Schlender et al. 2000). Both the cellular antiviral responses and IFN induction are suppressed by the action of NS1 and NS2 of both human and bovine RSV (Schlender et al. 2000; Bossert et al. 2003; Ling et al. 2009). In calves, tumor necrosis factor-alpha $(\mathrm{TNF}-\alpha)$ production differs according to the age (Antonis et al. 2010) besides the deficiency in TNF- $\alpha$ production by monocytes in newborns in response to TLR agonists, indicating the less serious RSV disease in babies and calves under a month of age (Levy 2007).

It is suggested that BRSV and HRSV NS proteins possess common mechanisms and cellular targets, and the NS proteins of both viruses showed a protective activity (Bossert and Conzelmann 2002). The two viral nonstructural proteins, NS1 and NS2, enable BRSV to escape from the cellular responses to IFN $-\alpha / \beta$. A chimeric BRSV with HRSV NS genes (BRSV h1/2) showed a differential IFN escape capacity in cells from different hosts, providing a basis for the rational development of live-attenuated RSV vaccines (Bossert and Conzelmann 2002).

HRSV and BRSV infection does not cause life-long immunity, and re-infection is usually subclinical (Van der Poel et al. 1994). HRSV and BRSV diseases share many features, such as similarity in disease development depends on age (Van der Poel et al. 1994; Grell et al. 2005; Antonis et al. 2010), unique lung histopathology (Bennett et al. 2007), BRSV co-infection with bacteria, such as Mannheimia and Haemophilus species (BRDC) (Srikumaran et al. 2007). It was also recorded that the significant similarities in the lung structural features with the overlapping clinical symptoms of respiratory disease 
(Kirschvink and Reinhold 2008). In temperate climates, both viruses cause annual winter respiratory disease outbreaks (Stott and Taylor 1985). The highest incidence of serious disease is in infants and calves under six months of age, and the majority of infections are to those 1-2 years of age (Stott and Taylor 1985). BRSV and HRSV replicate primarily in ciliated airway epithelial cells and type II pneumocytes (Viuff et al. 1996; Johnson et al. 2007; Welliver et al. 2008), and stimulate a variety of pro-inflammatory cytokines and chemokines (Valarcher and Taylor 2007; Bermejo-Martin et al. 2008; Rosenberg and Domachowske 2012), which direct the expression of cellular adhesion molecules and recruitment of neutrophils beside lymphocytes to the lung, resulting in bronchiolitis and interstitial pneumonia.

\section{Bovine and human coronaviruses (BCoV/HCoV)}

Coronaviruses $(\mathrm{CoV})$ are single-stranded positive-sense RNA, 26 to $32 \mathrm{~kb}$, enveloped, pleomorphic, 60 to $220 \mathrm{~nm}$ in diameter viruses, containing the spike (S) glycoproteins, approximately 12 to $25 \mathrm{~nm}$ in length (Saif et al. 2019). The subfamily Coronavirinae contains the four genera Alpha-, Beta-, Gamma-, and Deltacoronavirus (Corman et al. 2018). Coronaviruses (CoV) are common human and bovine pathogens, cause many infections such as enteric, respiratory, and neural infections. BCoV causes respiratory and enteric infections in cattle (Clark 1993) while HCoV isolate OC43 the causative agent of common cold in humans. In 1937, avian infectious bronchitis (IB) was the first characterized coronavirus (El-Sayed and Kamel 2021). Human coronaviruses $(\mathrm{HCoV})$ were identified in the 1960s and later, the bovine coronavirus (BCoV) in the 1970s (El-Sayed and Kamel 2021). To date, seven different CoVs have been identified in humans. HCoV-OC43 (McIntosh et al. 1967) and -229E (Hamre and Procknow 1966) were isolated for the first time in the 1960s. HCoV-NL63 (Van Der Hoek et al. 2004) and HKU1(Woo et al. 2005) were discovered only in 2004 and 2005, respectively. Three epidemic CoVs have emerged in humans in the last 2 decades, severe acute respiratory syndrome (SARS)-CoV, the Middle East respiratory syndrome (MERS)-CoV and severe acute respiratory syndrome 2 (SARS)-CoV-2 discovered in 2003, 2012 and 2019, respectively (Drosten et al. 2003; Zaki et al. 2012; Zhou et al. 2020).

Bovine coronaviruses $(\mathrm{BCoV})$ and human coronavirus OC43 (HCoV-OC43) belong to the family Coronaviridae, order Nidovirales, subfamily Coronavirinae. O-acetylated sialic acid or similar derivative are recognized by $\mathrm{HCoV}-\mathrm{OC} 43$ and $\mathrm{BCoV}$ as cell receptors (Vlasak et al. 1988) for viral binding and entry, and they are usually transmitted through the fecal-oral or respiratory route. On the contrary, SARS coronavirus and human coronavirus 229E (Matrosovich et al. 2015). $\mathrm{BCoV}$ is closely related to respiratory $\mathrm{HCoV}$ isolate $\mathrm{OC} 43$, they shared $95 \%$ genetic identity, suggesting that $\mathrm{BCoV}$ is an ancestor of human CoV-OC43 (Vijgen et al. 2005), or alternatively, they might have arisen from a common ancestor (Hasoksuz et al. 2007). Molecular clock analysis of genome sequences suggested that $\mathrm{HCoV}-\mathrm{OC} 43$ originated from a zoonotic transmission event of a bovine coronavirus (BCoV) and dated their most recent common ancestor between the $1890 \mathrm{~s}$ (Vijgen et al. 2005, 2006) and the 1950s (Lau et al. 2011). That is what led Vijgen et al. to theorize that the 1889-1890 "Russian flu" pandemic may have resulted in SARS-like interspecies transmission event, owing to the extensive depopulation of cattle herds between 1870 and 1890, which was associated with the highly pathogenic bovine respiratory disease (Greger 2007). BCoV, as a useful virus model, is paradigmatic of how CoVs are able to cross the interspecies barriers, establishing its derivatives as separate viral lineages affecting the respiratory and/or enteric tract of humans (HCoVOC43), swine (Porcine Hemagglutinating Encephalomyelitis Virus; PHEV), horses (equine coronavirus, ECoV), and dogs (canine respiratory coronavirus, CRCoV) (Decaro and Lorusso 2020), and that may be attributed to the accumulated genetic diversity of BCoVs (Zhang et al. 2007).

The global pandemic of Coronavirus Disease 2019 (COVID-19) has now infected nearly 160 million people worldwide, resulting in over 3.3 million deaths (WHO, 2021). Since its etiologic agent, SARS-CoV-2, was isolated and identified in early January 2020, the entire scientific community has been hardly working to find an effective cure and develop a vaccine to control the pandemic (Dhama et al. 2020a; Izda et al. 2020). Animal spillover and cross-species jumping events of SARS-CoV-2 have been identified, and zoonosis is being investigated (Dhama et al. 2020b; Tiwari et al. 2020; Sharun et al. 2021). Respiratory BCoV shares some common features with SARS-CoV and SARS-CoV-2, such as BCoV has a broad host-range (interspecies transmission) including wild ruminants, zoonotic potential, and respiratory and gastrointestinal tropisms (Saif and Jung 2020). Passive immunity in humans via the consumption of bovine immune milk (bovine immunoglobulins) has been studied for tens of years. Short-term protection against COVID-19 could be provided in humans as a result of drinking microfiltered immune milk from cows that were immunized against SARSCoV-2 (Jawhara 2020). Colostrum or antibodies-rich milk from cows can be used to treat human diseases caused by viruses and bacteria (Hurley and Theil 2011; Saied and Metwally 2019), such as SARS-CoV-2 (Jawhara 2020; Batista da Silva Galdino et al. 2021).

Transchromosomic bovines ( $\mathrm{TcB})$ offer a promising platform for the production of rapidly-produced fully human polyclonal immunoglobulin $\mathrm{G}$ ( $\mathrm{IgG}$ ) in large amounts for inhibition of Middle East Respiratory Syndrome coronavirus (MERS-CoV) in vivo (Luke et al. 2016). Only one MERS$\mathrm{CoV}$ neutralizing antibody (nAb) isolated from Tc has been evaluated in phase I trials (SAB-301) (Zhou et al. 2019), 
which showed safety and well tolerability in humans (Beigel et al. 2018). Interestingly, in a recent study, TcB was used to produce a polyclonal, fully human, anti-SARS-CoV-2 immunoglobulin (Liu et al. 2021) after hyperimmunization of TcB twice with plasmid DNA encoding the SARS-CoV-2 WuhanHu-1 strain Spike strain S gene (Wu et al. 2020), then repeatedly immunized with $\mathrm{S}$ protein purified from insect cells. The resultant anti-SARS-CoV-2 immunoglobulin was termed SAB-185 and efficiently neutralized SARS-CoV-2, and vesicular stomatitis virus (VSV) SARS-CoV-2 chimeras in vitro (Liu et al. 2021).

\section{Bovine-derived products}

Antibodies have been used in the therapy of infectious diseases since the late nineteenth century, in which von Behring and Kitasato have worked on using serum therapy for treating diphtheria and tetanus (Behring 1890). For more than a century, polyclonal immunoglobulin-based medicinal products have been used successfully to treat virus-caused illnesses. Many components in bovine milk have immunomodulatory and antimicrobial properties (Ulfman et al. 2018). For viral pathogens, immunized bovines give polyclonal IgG molecules which were shown to be effective in prophylaxis for human viruses such as HIV, human simplex virus (HSV), and SARS-CoV-2.

Cows that were immunized by a single Env trimer immunogen, generated bovine broadly neutralizing antibodies (bnAbs) with the characteristic long heavy-chain CDR3 loops to HIV (Sok et al. 2017). it has been suggested that bovines have the advantageous ability to generate super-antibodies against other human pathogens (Walker and Burton 2018). Colostrum from cows vaccinated with conventional bovine rotavirus vaccine, displayed antibodies with in vitro antihuman rotavirus activity (Civra et al. 2019). bIgG promotes adaptive antiviral $\mathrm{T}$ cell responses and protects against RSV infection in vitro and in vivo. Therefore, purified bIgG can be added to infant formulas to pass some of the beneficial effects of raw bovine milk to microbiologically stable infant formulas (Nederend et al. 2020), which not undergo heat treatment to avoid reducing the protective effect of bovine milk (Mainer et al. 1997; Loss et al. 2015). Bovine lactoferrin (BL), protein found in cow milk, indirectly reduces human norovirus infection via inducing the innate interferon responses (Oda et al. 2021) and has a therapeutic potential against SARS-CoV-2 (Batista da Silva Galdino et al. 2021). Additionally, BL is an effective modality against Zika and Chikungunya viruses (Carvalho et al. 2017). Lactoferrin may be useful in reducing the cytokine storm associated with severe COVID-19 infection (Kell et al. 2020), inhibiting the SARS-CoV-2 binding to the host cells (Kell et al. 2020).
In 1998, transgenic cattle were produced (Chan et al. 1998; Cibelli et al. 1998), and in 2002, transchromosomal cattle were used to produce human polyclonal antibodies (hPABs) as useful therapeutic agents (Kuroiwa et al. 2002) via introducing human artificial chromosome (HAC) vector into bovine primary fetal fibroblasts using a microcell-mediated chromosome transfer (MMCT) approach. Human albumin serum (HAS), a human plasma protein, was produced in the mammary gland of transgenic cattle (Kues and Niemann 2004) and entered phase I trials for production of recombinant human serum albumin (rHSA) in humans. When transchromosomic bovines $(\mathrm{TcB})$ were vaccinated, fully human $\operatorname{IgG}$ produced that does not need enzymatic treatment to prevent anaphylactic reaction and serum sickness associated with heterologous species IgG. Furthermore, human IgG from $\mathrm{TcB}$ has a longer half-life and retains the effector functions associated with the $\mathrm{Fc}$, removed by enzyme treatment. Human $\mathrm{IgG}$ from $\mathrm{TcB}$ also provides medical products based on polyclonal immunoglobulin without the need for human donors or inactivated/ attenuated vaccine antigens (Hooper et al. 2014). Transchromosomal cows have also been used to rapidly generate fully polyclonal neutralizing antibodies to MERS-CoV, Hantavirus, Venezuelan equine encephalitis virus, and Ebola virus (Hooper et al. 2014; Dye et al. 2016; Luke et al. 2016; Gardner et al. 2017; Beigel et al. 2018), showing the feasibility of using this platform to develop therapeutics to tackle emerging viral threats. Perhaps the first step in the road to $\mathrm{mAb}$ isolation from $\mathrm{TcB}$ has been done through yielding both polyclonal (SAB-100) and monoclonal (53C10) antibodies produced from the transchromosomic (Tc) cattle platform against influenza viruses. $53 \mathrm{C} 10 \mathrm{mAb}$ was capable of neutralizing diverse clades of the hemagglutinin-1 (H1) subtype indicating its potential role in treating $\mathrm{H} 1$ influenza virus infection in humans (Gao et al. 2020). The transgenic technology in bovines would solve many disadvantages of biopharmaceutical products such as immunogenicity, biosafety, costcompetitive (Redwan 2009), and production of therapeutic antibodies on a large scale. Transgenic cattle act as a novel model for infectious and non-infectious diseases. A novel glycosylated anti-CD20 monoclonal antibody was produced in the milk of transgenic cattle demonstrated superior efficacy over Rituxan, the first therapeutic recombinant monoclonal antibodies $(\mathrm{mAb})$ to treat non-Hodgkin lymphoma (GrilloLópez et al. 1999), against B-cell lymphomas in severe combined immunodeficiency mice (Zhang et al. 2018). Antibodies produced in $\mathrm{TcB}$ could solve the respiratory virusesassociated antibody-dependent enhancement (ADE) phenomena (Weingartl et al. 2004; Tseng et al. 2012). Recent studies showed that the anti-SARS-CoV-2 antibodies (antibodybased vaccines) could increase the severity of COVID-19 (Arvin et al. 2020; Lee et al. 2020) and multiple viral infections such as RSV (Graham 2016) and measles (Polack 2007) through $\mathrm{ADE}$, which results in failed vaccine trials. 


\section{Concerns and precautions}

Pathogens infecting livestock can come from wild animals as an infection or re-infection (Gortázar et al. 2007; Conner et al. 2008) and viruses, in particular, few RNA viruses such as MERS-CoV and Hendra virus (Cunningham et al. 2017), are the main and the most recently emerged pathogens of wildlife (Dobson and Foufopoulos 2001; Pedersen et al. 2007) (Fig. 4). Many newly identified human virus species have been found in humans for a considerable time but have only recently been recognized (Woolhouse and Gaunt 2007). Viruses undergo a biological evolution according to the evolutionary history of life. But, at the time of their discovery, an interesting question will arise: where these viruses firstly originated in animals or humans? More than half of pathogens that infect humans can infect other hosts (Woolhouse and GowtageSequeria 2005), and most pathogens in farm animal populations are in human communities (Pearce-Duvet 2006; Lanzas et al. 2010). The high population densities of farm animals result in increased rates of pathogen transmission, acting as sources for emerging viruses for humans (Cleaveland et al. 2001; Morse et al. 2012). Human pathogens (189 (13.5\%) of 1399 ) are viruses ( $\sim 81 \%$ RNA viruses and $\sim 19 \%$ DNA viruses), but in the last 40 years, there is an increase in the novel viruses much faster than other pathogens (Woolhouse and Gaunt 2007) especially in presence of new technologies (Morales-Sánchez and Fuentes-Pananá 2014). Twenty-three percent of all malignancies in humans are associated with pathogenic organisms (Organization 2003; zur Hausen 2009;
Brücher and Jamall 2014), mostly viruses (Ewald and Swain Ewald 2015). Bovines are one of the most common animal species that are directly or indirectly responsible for transmitting infections from animals to humans (Baechlein et al. 2015). In addition to being an important food source, this is due to their high population density and diversity in communication with humans and other species (Lu et al. 2018). Most non-human milk consumed by humans comes from cows, as this animal is used extensively in commercial production. Bovine meat consumption comes in the third rank after pig meat and poultry, respectively. Antimicrobial-resistant pathogens through food intake (meat or milk), direct contact with patient animals, waste management, and the use of manure as fertilizer, can be transmitted from cattle to humans (Marshall and Levy 2011). Interestingly and according to the phylogenetic studies, cattle were also recipients of parasites and microbes that spread from humans (Morand et al. 2014).

Concerns about using bovine materials from infected with bovine spongiform encephalopathy-infected cattle (BSE), such as bone, serum, and tissue of the nervous system, which could transmit the infectious agent to people, where Creutzfeldt-Jakob (CJD) disease could be caused. The benefit of vaccination outweighs the potential risk of vaccine contamination (Marwick 2000). Also, the same concerns are about using of vaccines, produced on allogeneic cell lines in humans (Benedictus and Bell 2017), and colostrum-containing dietary supplements (Kasonta et al. 2014) from PregSure-treated cows, PregSure is an inactivated BVD vaccine for cattle, but their risk for the reaction of transmitting alloantibodies, that

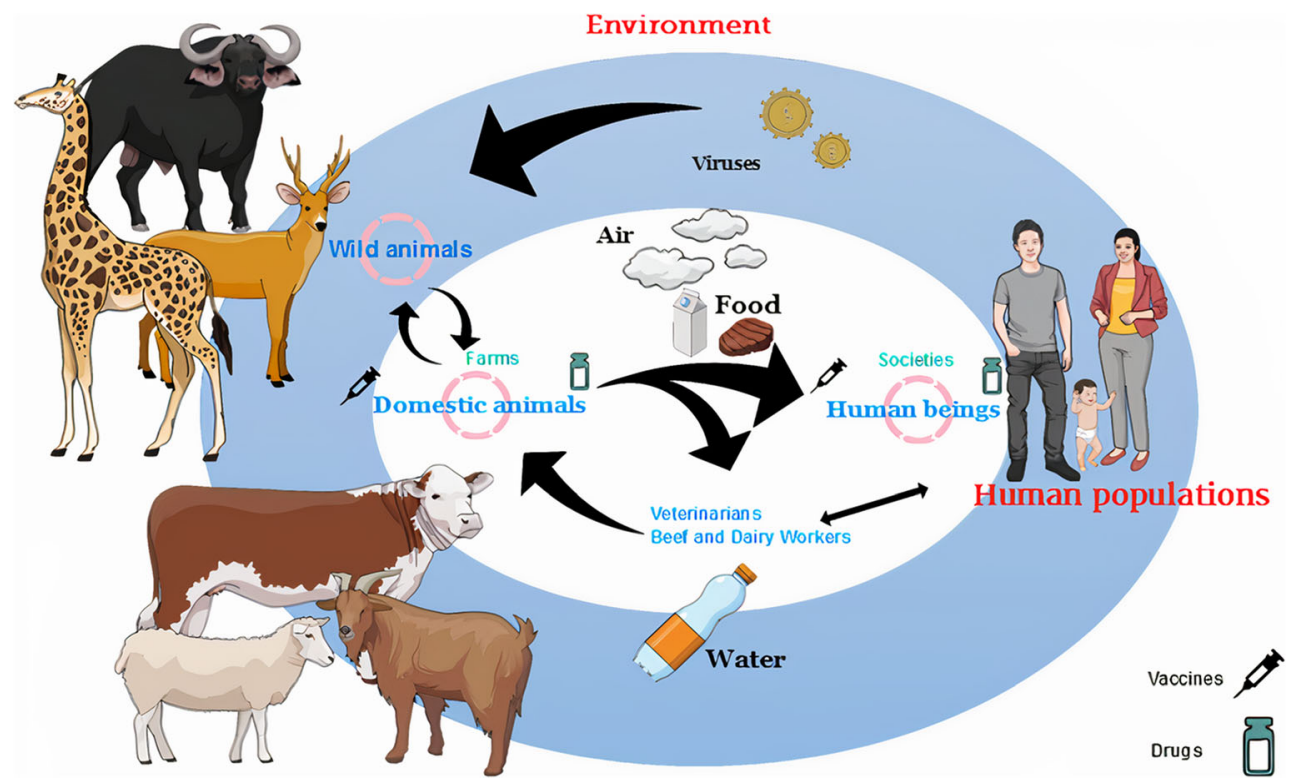

Fig. 4 The possible ways of transmission of viruses. Viruses are present around in the environment as inactive microbes where the life cycle of viruses begins after entering the living body. Wild animals are reservoir hosts for many emerging viruses, and bovines play an important role in the spread of viruses from wildlife to a human directly or indirectly. Furthermore, the air, water, and food are other routes of transmission of viruses besides the anthropogenic activities leading to pathogen spillover. Vaccination of farm animals, including bovines, is the strategy for improving animal health and protecting human health, and medicines are valuable and urgent against diseases that do not possess vaccines until now 
responsible for developing bovine neonatal pancytopenia (BNP) in cattle, to human lymphoblasts is not totally scientifically confirmed.

\section{Conclusion}

"And there is no creature on (or inside) the earth or a bird that flies with its wings except (that they are) nations like you." (Cattle 38), the Noble Quran (Saied and Metwally 2019). Although there are differences between bovines and humans, the similarities are not tiny or far. The convergence of human health with animal health, under the concept of One Health, opens a new dimension in this era for solving and controlling many urgent topics. The idea of exploiting certain bovine characteristics to learn about human viral infections is gaining widespread application. Bovines can make significant, rapid contributions to better understand and improve therapies for human viral infections. "In our battle with microbes, we have a number of weapons in our armamentarium" Dr. Anthony S. Fauci said, is one of the world's leading experts on infectious diseases. Viral diseases are an important challenge to the health of the public worldwide. Unfortunately, most viral diseases are often asymptomatic in humans and cattle; the need for survey by using advanced technologies in diagnosis is a prompt need. All that suggested the presence of zoonotic diseases but in a hidden mask. Scientists are striving to find out drugs and vaccines due to the urgent need to combat viral diseases, especially in their speed pace.

Bovine could be used for, via their immunization with a specific human virus, the production of broadly neutralizing antibodies, in serum and colostrum of bovines, against human viruses such as HIV, MERS-CoV, and Hantavirus (reviewed in (Saied and Metwally 2019)) besides using transchromosomic (TcB) bovines as a platform for producing human polyclonal and monoclonal antibodies as a therapeutic modality to combat emerging viral threats such as MERS-CoV, Hantavirus, Venezuelan equine encephalitis virus, influenza virus, and Ebola virus, and provides a possible strategy for developing passive immunotherapy against coronaviruses such as SARS-CoV2. Bovine viruses-based vaccines such as RotaTeq vaccine and a live-attenuated BPIV-3 vaccine were showed their safety and well tolerance in humans and infants at the age of 12-18 months. Other human vaccines that are based on bovine viruses have shown promising results. As well recent studies reported using bovine viruses-based therapies such as BVD in treating MM and $\mathrm{BPV}$ in treating prostate cancers.

Prevention of transmission of zoonotic pathogens from the bovine-derived products into the clinical application into human health is a crucial aspect that requires sensitive and reliable screening methods. Associated with the somatic cloning technology, conditional gene expression, and gene targeting will make cattle non-susceptible to spongiform encephalopathy (BSE), and give the scientists the chance to create useful bovine models for human diseases and as preclinical testing for vaccines. Exclusion of colostrum collected from PregSure-treated cows for colostrum powder manufacturing should be taken into account (Kasonta et al. 2014). Overall, bovines and their products showed promising outputs that warrant further research to clarify their contribution to this field and against other viruses such as influenza viruses and COVID-19. Future work including bovine viruses for vaccine development and $\mathrm{TcB}$ as a platform for the generation of human poly and mono antibodies against human viruses is crucial. This review is the first of its type that describes some human viruses for which bovines have contributed to their combating, offering different aspects of benefits from using bovines against human viral infections. We are sure the review topic will reshape the recent future.

Acknowledgements AbdulRahman A. Saied is grateful to the Ministry of Tourism and Antiquities and the National Food Safety Authority (NFSA) for their encouragement and support. We are grateful to the three reviewers for their kind words and constructive comments that led to clear improvement of the manuscript.

Author contribution Conceptualization, Collection of literature, Investigation; AbdulRahman A. Saied; Data analysis, Interpretation, resources, Writing - original draft: AbdulRahman A. Saied, Asmaa A. Metwally; Funding acquisition: AbdulRahman A. Saied, Asmaa A. Metwally, Hams M.A. Mohamed, Mohie A.M. Haridy; Supervision: AbdulRahman A. Saied., Mohie A.M. Haridy; Writing-review \& editing: AbdulRahman A. Saied, Asmaa A. Metwally, Mohie A.M. Haridy.

Funding The authors declared that they have not got any funds anywhere.

Data availability All data related to this publication are made available in the article.

\section{Declarations}

Ethics approval This manuscript does not contain any studies with animals performed by any of the authors.

Consent for publication This manuscript does not contain any studies with human participants performed by any of the authors.

Consent to publish This article has the consent of all the authors and authors have no conflicts of interest.

Competing interests The authors declare no competing interests.

\section{References}

Abed Y, St-Laurent G, Zhang H et al (1999) Development of a western blot assay for detection of bovine immunodeficiency-like virus using capsid and transmembrane envelope proteins expressed from 
recombinant baculovirus. Clin Diagn Lab Immunol 6:168-172. https://doi.org/10.1128/cdli.6.2.168-172.1999

Achachi A, Florins A, Gillet N et al (2005) Valproate activates bovine leukemia virus gene expression, triggers apoptosis, and induces leukemia/lymphoma regression in vivo. Proc Natl Acad Sci 102: 10309-10314

Adams MJ, Lefkowitz EJ, King AMQ et al (2016) Ratification vote on taxonomic proposals to the International Committee on Taxonomy of Viruses (2016). Arch Virol 161:2921-2949

Aida Y, Murakami H, Takagashi M, Takeshima S-N (2013) Mechanisms of pathogenesis induced by bovine leukemia virus as a model for human T-cell leukemia virus. Front Microbiol 4:328

Alberti A, Pirino S, Pintore F et al (2010) Ovis aries Papillomavirus 3: a prototype of a novel genus in the family Papillomaviridae associated with ovine squamous cell carcinoma. Virology 407:352-359

Angel J, Franco MA, Greenberg HB (2007) Rotavirus vaccines: recent developments and future considerations. Nat Rev Microbiol 5:529 539

Antonis AFG, de Jong MC, van der Poel WHM et al (2010) Agedependent differences in the pathogenesis of bovine respiratory syncytial virus infections related to the development of natural immunocompetence. J Gen Virol 91:2497-2506

Antonsson A, Forslund O, Ekberg $\mathrm{H}$ et al (2000) The ubiquity and impressive genomic diversity of human skin papillomaviruses suggest a commensalic nature of these viruses. J Virol 74:11636-11641

Antonsson A, Nancarrow DJ, Brown IS et al (2010) High-risk human papillomavirus in esophageal squamous cell carcinoma. Cancer Epidemiol Prev Biomark 19:2080-2087

Araldi RP, Módolo DG, de Sa Junior PL et al (2016) Genetics and metabolic deregulation following cancer initiation: a world to explore. Biomed Pharmacother 82:449-458

Arbyn M, Castellsagué X, de Sanjosé S et al (2011) Worldwide burden of cervical cancer in 2008. Ann Oncol 22:2675-2686

Arvin AM, Fink K, Schmid MA et al (2020) A perspective on potential antibody-dependent enhancement of SARS-CoV-2. Nature 584: 353-363

Athanassiou Z, Patora K, Dias RLA et al (2007) Structure-Guided Peptidomimetic Design Leads to Nanomolar $\beta$-Hairpin Inhibitors of the Tat- TAR Interaction of Bovine Immunodeficiency Virus. Biochemistry 46:741-751

Atreya PL, Kulkarni S (1999) Respiratory syncytial virus strain A2 is resistant to the antiviral effects of type I interferons and human MxA. Virology 261:227-241

August A, Glenn GM, Kpamegan E et al (2017) A Phase 2 randomized, observer-blind, placebo-controlled, dose-ranging trial of aluminumadjuvanted respiratory syncytial virus $\mathrm{F}$ particle vaccine formulations in healthy women of childbearing age. Vaccine 35:3749-3759

Avidan O, Bochner R, Hizi A (2006) The catalytic properties of the recombinant reverse transcriptase of bovine immunodeficiency virus. Virology 351:42-57

Baechlein C, Fischer N, Grundhoff A et al (2015) Identification of a novel hepacivirus in domestic cattle from Germany. J Virol 89:7007-7015

Baginski SG, Pevear DC, Seipel M et al (2000) Mechanism of action of a pestivirus antiviral compound. Proc Natl Acad Sci 97:7981-7986

Bailly JE, Mcauliffe JM, Skiadopoulos MH et al (2000) Sequence determination and molecular analysis of two strains of bovine parainfluenza virus type 3 that are attenuated for primates. Virus Genes 20:173-182

Baker JC (1995) The clinical manifestations of bovine viral diarrhea infection. Vet Clin North Am Food Anim Pract 11:425-445

Baker TS, Newcomb WW, Olson NH et al (1991) Structures of bovine and human papillomaviruses. Analysis by cryoelectron microscopy and three-dimensional image reconstruction. Biophys J 60:14451456
Balcos LGF, Borzacchiello G, Russo V et al (2008) Association of bovine papillomavirus type- 2 and urinary bladder tumours in cattle from Romania. Res Vet Sci 85:145-148

Baldwin CL, Telfer JC (2015) The bovine model for elucidating the role of $\gamma \delta \mathrm{T}$ cells in controlling infectious diseases of importance to cattle and humans. Mol Immunol 66:35-47

Ballard-Croft C, Wang D, Sumpter LR et al (2012) Large-animal models of acute respiratory distress syndrome. Ann Thorac Surg 93:13311339

Bam J, Kumar P, Leishangthem GD et al (2013) Spontaneous cutaneous papillomatosis in yaks and detection and quantification of bovine papillomavirus-1 and-2. Transbound Emerg Dis 60:475-480

Barré-Sinoussi F, Chermann J-C, Rey F et al (1983) Isolation of a Tlymphotropic retrovirus from a patient at risk for acquired immune deficiency syndrome (AIDS). Science 220:868-871

Bartlett EJ, Castaño A, Surman SR et al (2007) Attenuation and efficacy of human parainfluenza virus type 1 (HPIV1) vaccine candidates containing stabilized mutations in the $\mathrm{P} / \mathrm{C}$ and $\mathrm{L}$ genes. Virol J 4:67

Batista da Silva Galdino A, do Nascimento Rangel AH, Buttar HS et al (2021) Bovine colostrum: benefits for the human respiratory system and potential contributions for clinical management of COVID-19. Food Agric Immunol 32:143-162

Behring E v (1890) Ueber das zustandekommen der diphtherieimmunität und der tetanus-immunität bei thieren. In: Drucke $19 \mathrm{Jh}$

Beigel JH, Voell J, Kumar P et al (2018) Safety and tolerability of a novel, polyclonal human anti-MERS coronavirus antibody produced from transchromosomic cattle: a phase 1 randomised, double-blind, single-dose-escalation study. Lancet Infect Dis 18:410-418

Belshe RB, Van Voris LP, Mufson MA (1982) Parenteral administration of live respiratory syncytial virus vaccine: results of a field trial. J Infect Dis 145:311-319

Bem RA, Domachowske JB, Rosenberg HF (2011) Animal models of human respiratory syncytial virus disease. Am J Phys Lung Cell Mol Phys 301:L148-L156. https://doi.org/10.1152/ajplung.00065.2011

Benedictus L, Bell CR (2017) The risks of using allogeneic cell lines for vaccine production: the example of Bovine Neonatal Pancytopenia. Expert Rev Vaccines 16:65-71

Bennett N, Ellis J, Bonville C et al (2007) Immunization strategies for the prevention of pneumovirus infections. Expert Rev Vaccines 6:169 182

Beran J, Lickliter JD, Schwarz TF et al (2018) Safety and immunogenicity of 3 formulations of an investigational respiratory syncytial virus vaccine in nonpregnant women: results from 2 phase 2 trials. J Infect Dis 217:1616-1625

Bermejo-Martin JF, Tenorio A, Ortiz de Lejarazu R et al (2008) Similar cytokine profiles in response to infection with respiratory syncytial virus type $\mathrm{A}$ and type $\mathrm{B}$ in the upper respiratory tract in infants. Intervirology 51:112-115. https://doi.org/10.1159/000134268

Bernard H-U (1994) Coevolution of papiliomaviruses with human populations. Trends Microbiol 2:140-143

Bernard H-U, Burk RD, Chen Z et al (2010) Classification of papillomaviruses (PVs) based on $189 \mathrm{PV}$ types and proposal of taxonomic amendments. Virology 401:70-79

Bhatia S, Patil SS, Sood R (2013) Bovine immunodeficiency virus: a lentiviral infection. Indian J Virol 24:332-341

Bhattacharyya R, Bhattacharya S, Wenzel-Mathers M, Buckwold VE (2003) Phyllanthus amarus root clone with significant activity against bovine viral diarrhoea virus-a surrogate model of hepatitis C virus. Curr Sci 84:529-533

Bishop R, Davidson GP, Holmes IH, Ruck BJ (1973) Virus particles in epithelial cells of duodenal mucosa from children with acute nonbacterial gastroenteritis. Lancet 302:1281-1283

Blodörn K, Hägglund S, Fix J et al (2014) Vaccine safety and efficacy evaluation of a recombinant bovine respiratory syncytial virus (BRSV) with deletion of the SH gene and subunit vaccines based on recombinant human RSV proteins: N-nanorings, $\mathrm{P}$ and M2-1, in 
calves with maternal antibodies. PLoS One 9:e100392. https://oi. org/10.1371/journal.pone. 0100392

Bocaneti F, Altamura G, Corteggio A et al (2016) Bovine papillomavirus: new insights into an old disease. Transbound Emerg Dis 63:14-23

Bogaert L, Van Poucke M, De Baere C et al (2007) Bovine papillomavirus load and mRNA expression, cell proliferation and p53 expression in four clinical types of equine sarcoid. J Gen Virol 88:21552161

Borysiewicz LK, Fiander A, Nimako M et al (1996) A recombinant vaccinia virus encoding human papillomavirus types 16 and 18 , E6 and E7 proteins as immunotherapy for cervical cancer. Lancet 347:1523-1527

Borzacchiello G (2007) Bovine papillomavirus infections in animals. Commun Curr Res Educ Top trends Appl Microbiol 2007:2

Borzacchiello G, Roperto F (2008) Bovine papillomaviruses, papillomas and cancer in cattle. Vet Res 39:1

Borzacchiello G, Ambrosio V, Roperto S et al (2003) Bovine papillomavirus type 4 in oesophageal papillomas of cattle from the south of Italy. J Comp Pathol 128:203-206

Bosch FX, Lorincz A, Muñoz N et al (2002) The causal relation between human papillomavirus and cervical cancer. J Clin Pathol 55:244 265

Bossert B, Conzelmann K-K (2002) Respiratory syncytial virus (RSV) nonstructural (NS) proteins as host range determinants: a chimeric bovine RSV with NS genes from human RSV is attenuated in interferon-competent bovine cells. J Virol 76:4287-4293

Bossert B, Marozin S, Conzelmann K-K (2003) Nonstructural proteins NS1 and NS2 of bovine respiratory syncytial virus block activation of interferon regulatory factor 3. J Virol 77:8661-8668

Bouma A, Elbers ARW, Dekker A et al (2003) The foot-and-mouth disease epidemic in The Netherlands in 2001. Prev Vet Med 57: $155-166$

Bravo IG, de Sanjosé S, Gottschling M (2010) The clinical importance of understanding the evolution of papillomaviruses. Trends Microbiol $18: 432-438$

Bright RA, Carter DM, Daniluk S et al (2007) Influenza virus-like particles elicit broader immune responses than whole virion inactivated influenza virus or recombinant hemagglutinin. Vaccine 25:38713878

Brücher BLDM, Jamall IS (2014) Epistemology of the origin of cancer: a new paradigm. BMC Cancer 14:1-15

Brzoska L, Fischer M, Lentz HHK (2020) Hierarchical Structures in Livestock Trade Networks-A Stochastic Block Model of the German Cattle Trade Network. Front Vet Sci 7:281

Buckwold VE, Beer BE, Donis RO (2003) Bovine viral diarrhea virus as a surrogate model of hepatitis $\mathrm{C}$ virus for the evaluation of antiviral agents. Antivir Res 60:1-15

Buddle BM, Skinner MA, Wedlock DN et al (2005) Cattle as a model for development of vaccines against human tuberculosis. Tuberculosis 85:19-24

Buehring GC, Kramme PM, Schultz RD (1994) Evidence for bovine leukemia virus in mammary epithelial cells of infected cows. Lab Investig 71:359-365

Callahan R, Lieber MM, Todaro GJ et al (1976) Bovine leukemia virus genes in the DNA of leukemic cattle. Science 192:1005-1007

Campo MS (1988) Viral and cellular oncogenes in papillomavirusassociated cancers. Br J Cancer Suppl 9:80

Campo MS (1997) Vaccination against papillomavirus in cattle. Clin Dermatol 15:275-283

Campo MS (2006) Bovine papillomavirus: old system, new lessons?

Campo MS, Roden RBS (2010) Papillomavirus prophylactic vaccines: established successes, new approaches. J Virol 84:1214-1220

Campo MS, Jarrett WFH, Barron R et al (1992) Association of bovine papillomavirus type 2 and bracken fern with bladder cancer in cattle. Cancer Res 52:6898-6904
Campos SRC, Melo TC, Assaf S et al (2013) Chromosome aberrations in cells infected with bovine papillomavirus: comparing cutaneous papilloma, esophagus papilloma, and urinary bladder lesion cells. Int Sch Res Not 2013:910849

Carpenter S, Miller LD, Alexandersen S et al (1992) Characterization of early pathogenic effects after experimental infection of calves with bovine immunodeficiency-like virus. J Virol 66:1074-1083

Carvalho CCR, Batista MVA, Silva MAR et al (2012) Detection of bovine papillomavirus types, co-infection and a putative new BPV11 subtype in cattle. Transbound Emerg Dis 59:441-447

Carvalho CAM, Casseb SMM, Gonçalves RB et al (2017) Bovine lactoferrin activity against Chikungunya and Zika viruses. J Gen Virol 98:1749-1754

Castilow EM, Olson MR, Varga SM (2007) Understanding respiratory syncytial virus (RSV) vaccine-enhanced disease. Immunol Res 39: 225-239

Chan AWS, Homan EJ, Ballou LU et al (1998) Transgenic cattle produced by reverse-transcribed gene transfer in oocytes. Proc Natl Acad Sci 95:14028-14033

Chaturvedi AK, Madeleine MM, Biggar RJ, Engels EA (2009) Risk of human papillomavirus-associated cancers among persons with AIDS. J Natl Cancer Inst 101:1120-1130

Chauhan RS, Singh NP (1996) Epidemiology of rotavirus infection in calves. Int J Anim Sci 11:221-223

Chen G, Willems L, Portetelle D et al (1989) Synthesis of functional bovine leukemia virus (BLV) p34tax protein by recombinant baculoviruses. Virology 173:343-347

Choo QL, Weiner AJ, Overby LR et al (1990) Hepatitis C virus: the major causative agent of viral non-A, non-B hepatitis. Br Med Bull 46: 423-441

Cibelli JB, Stice SL, Golueke PJ et al (1998) Cloned transgenic calves produced from nonquiescent fetal fibroblasts. Science 280:12561258

Civra A, Altomare A, Francese R et al (2019) Colostrum from cows immunized with a veterinary vaccine against bovine rotavirus displays enhanced in vitro anti-human rotavirus activity. J Dairy Sci 102:4857-4869

Clark MA (1993) Bovine coronavirus. Br Vet J 149:51-70

Clark HF, Offit PA, Plotkin SA, Heaton PM (2006) The new pentavalent rotavirus vaccine composed of bovine (strain WC3)-human rotavirus reassortants. Pediatr Infect Dis J 25:577-583

Claus MP, Lunardi M, Alfieri AA et al (2009) Multiple bovine papillomavirus infections associated with cutaneous papillomatosis in Brazilian cattle herds. Braz Arch Biol Technol 52:93-98

Cleaveland S, Laurenson MK, Taylor LH (2001) Diseases of humans and their domestic mammals: pathogen characteristics, host range and the risk of emergence. Philos Trans R Soc Lond Ser B Biol Sci 356: 991-999

Coelingh KJ, Winter CC, Murphy BR et al (1986) Conserved epitopes on the hemagglutinin-neuraminidase proteins of human and bovine parainfluenza type 3 viruses: nucleotide sequence analysis of variants selected with monoclonal antibodies. J Virol 60:90-96

Colby LA, Quenee LE, Zitzow LA (2017) Considerations for infectious disease research studies using animals. Comp Med 67:222-231

Coleman PG, Perry BD, Woolhouse MEJ (2001) Endemic stability-a veterinary idea applied to human public health. Lancet 357:1284 1286

Conner MM, Ebinger MR, Blanchong JA, Cross PC (2008) Infectious disease in cervids of North America: data, models, and management challenges. Ann N Y Acad Sci 1134:146

Corman VM, Grundhoff A, Baechlein C et al (2015) Highly divergent hepaciviruses from African cattle. J Virol 89:5876-5882

Corman VM, Muth D, Niemeyer D, Drosten C (2018) Hosts and sources of endemic human coronaviruses. Adv Virus Res 100:163-188

Cotchin E (1962) Problems of comparative oncology: With special reference to the veterinary aspects. Bull World Health Organ 26:633 
Cotchin E (1976) Comparative oncology: The veterinary contribution. Proc R Soc Med 69(9):649-656

Crawford LV, Crawford EM (1963) A comparative study of polyoma and papilloma viruses. Virology 21:258-263

Cuesta LM, Lendez PA, Farias MVN et al (2018) Can bovine leukemia virus be related to human breast cancer? A review of the evidence. J Mammary Gland Biol Neoplasia 23:101-107

Cunningham AA, Daszak P, Wood JLN (2017) One Health, emerging infectious diseases and wildlife: two decades of progress? Philos Trans R Soc B Biol Sci 372:20160167

Das S, Palmer OP, Leight WD et al (2005) Cytokine amplification by respiratory syncytial virus infection in human nasal epithelial cells. Laryngoscope 115:764-768. https://doi.org/10.1097/01.MLG. 0000159527.76949 .93

Daudt C, Da Silva FRC, Lunardi M et al (2018) Papillomaviruses in ruminants: An update. Transbound Emerg Dis 65:1381-1395

Day PM, Gambhira R, Roden RBS et al (2008) Mechanisms of human papillomavirus type 16 neutralization by 12 cross-neutralizing and 11 type-specific antibodies. J Virol 82:4638-4646

Day PM, Kines RC, Thompson CD et al (2010) In vivo mechanisms of vaccine-induced protection against HPV infection. Cell Host Microbe 8:260-270

De Clercq E (2007) The design of drugs for HIV and HCV. Nat Rev Drug Discov 6:1001-1018

De Francesco R, Migliaccio G (2005) Challenges and successes in developing new therapies for hepatitis C. Nature 436:953-960

de Villiers E-M (2013) Cross-roads in the classification of papillomaviruses. Virology 445:2-10

Decaro N, Lorusso A (2020) Novel human coronavirus (SARS-CoV-2): A lesson from animal coronaviruses. Vet Microbiol 244:108693

Dhama K, Khan S, Tiwari R et al (2020a) Coronavirus disease 2019 COVID-19. Clin Microbiol Rev 33:e00028-e00020

Dhama K, Patel SK, Sharun K et al (2020b) SARS-CoV-2 jumping the species barrier: zoonotic lessons from SARS, MERS and recent advances to combat this pandemic virus. Travel Med Infect Dis 37:101830

Dillner J, Knekt P, Schiller JT, Hakulinen T (1995) Prospective seroepidemiological evidence that human papillomavirus type 16 infection is a risk factor for oesophageal squamous cell carcinoma. Bmj 311:1346

Dobson A, Foufopoulos J (2001) Emerging infectious pathogens of wildlife. Philos Trans R Soc Lond Ser B Biol Sci 356:1001-1012

Doorbar J, Quint W, Banks L et al (2012) The biology and life-cycle of human papillomaviruses. Vaccine 30:F55-F70

Drosten C, Günther S, Preiser W et al (2003) Identification of a novel coronavirus in patients with severe acute respiratory syndrome. $\mathrm{N}$ Engl J Med 348:1967-1976

Drummer HE (2014) Challenges to the development of vaccines to hepatitis $\mathrm{C}$ virus that elicit neutralizing antibodies. Front Microbiol 5: 329

Dubé C, Ribble C, Kelton D, McNab B (2009) A review of network analysis terminology and its application to foot-and-mouth disease modelling and policy development. Transbound Emerg Dis 56:7385

Durbin AP, Karron RA (2003) Progress in the development of respiratory syncytial virus and parainfluenza virus vaccines. Clin Infect Dis 37: 1668-1677

Dvoretzky I, Shober R, Chattopadhyay SK, Lowy DR (1980) A quantitative in vitro focus assay for bovine papilloma virus. Virology 103 : 369-375

Dye JM, Wu H, Hooper JW et al (2016) Production of potent fully human polyclonal antibodies against Ebola Zaire virus in transchromosomal cattle. Sci Rep 6:1-9

Easton AJ, Domachowske JB, Rosenberg HF (2004) Animal pneumoviruses: molecular genetics and pathogenesis. Clin
Microbiol Rev 17:390-412. https://doi.org/10.1128/cmr.17.2.390412.2004

Egger JR, Ooi EE, Kelly DW et al (2008) Reconstructing historical changes in the force of infection of dengue fever in Singapore: implications for surveillance and control. Bull World Health Organ 86:187-196

El-Sayed A, Kamel M (2021) Coronaviruses in humans and animals: the role of bats in viral evolution. Environ Sci Pollut Res 28:1958919600

Estes MK, Cohen J (1989) Rotavirus gene structure and function. Microbiol Mol Biol Rev 53:410-449

Estes MK, Greenberg HB (2013) Rotaviruses. In: Fields Virol, 6th edn. Lippincott Williams Wilkins, Philadelphia, pp 1347-1401

Everard ML, Milner AD (1992) The respiratory syncitial virus and its role in acute bronchiolitis. Eur J Pediatr 151:638-651

Everts-van der Wind A, Larkin DM, Green CA et al (2005) A highresolution whole-genome cattle-human comparative map reveals details of mammalian chromosome evolution. Proc Natl Acad Sci 102:18526-18531

Ewald PW, Swain Ewald HA (2015) Infection and cancer in multicellular organisms. Philos Trans R Soc B Biol Sci 370:20140224

Fach SJ, Olivier A, Gallup JM et al (2010) Differential expression of cytokine transcripts in neonatal and adult ovine alveolar macrophages in response to respiratory syncytial virus or toll-like receptor ligation. Vet Immunol Immunopathol 136:55-64. https://doi.org/10. 1016/j.vetimm.2010.02.008

Falsey AR, Hennessey PA, Formica MA et al (2005) Respiratory Syncytial Virus Infection in Elderly and High-Risk Adults. N Engl J Med 352:1749-1759. https://doi.org/10.1056/NEJMoa043951

Farzani TA, Dagalp SB, Ozkul A et al (2021) Assessment of replication of bovine herpesvirus type 4 in human glioblastoma and breast cancer cells as a potential oncolytic virus. Virus Genes 57:31-39

Felin IPD, Grivicich I, Felin CR et al (2008) Expressão de p53, p16 e COX-2 em carcinoma escamoso de esôfago e associaçao histopatológica. Arq Gastroenterol 45:308-312

Flewett TH, Bryden AS, Davies H (1973) Virus particles in gastroenteritis. Virus Part gastroenteritis. Lancet 2(7844):1497

Franchini G, Fukumoto R, Fullen JR (2003) T-cell control by human Tcell leukemia/lymphoma virus type 1. Int J Hematol 78:280-296

Franco MA, Angel J, Greenberg HB (2006) Immunity and correlates of protection for rotavirus vaccines. Vaccine $24: 2718-2731$

Fuentes S, Tran KC, Luthra P et al (2007) Function of the Respiratory Syncytial Virus Small Hydrophobic Protein. J Virol 81:8361-8366. https://doi.org/10.1128/jvi.02717-06

Fulginiti VA, Eller JJ, Sieber OF et al (1969) Respiratory virus immunization: a field trial of two inactivated respiratory virus vaccines; an aqueous trivalent paratnfluenza virus vaccine and an alumprecipitated Respiratory Syncytial Virus vaccine. Am J Epidemiol 89:435-448

Gallo RC (2005) The discovery of the first human retrovirus: HTLV-1 and HTLV-2. Retrovirology 2:17

Gallo RC, Sarin PS, Gelmann EP et al (1983) Isolation of human T-cell leukemia virus in acquired immune deficiency syndrome (AIDS). Science 220:865-867. https://doi.org/10.1126/science.6601823

Gambhira R, Karanam B, Jagu S et al (2007) A protective and broadly cross-neutralizing epitope of human papillomavirus L2. J Virol 81: 13927-13931

Gao R, Sreenivasan CC, Sheng Z et al (2020) Human Monoclonal Antibody Derived from Transchromosomic Cattle Neutralizes Multiple H1 Clades of Influenza A Virus by Recognizing a Novel Conformational Epitope in the Hemagglutinin Head Domain. J Virol 94:e00945-e00920

García-Vallvé S, Alonso Á, Bravo IG (2005) Papillomaviruses: different genes have different histories. Trends Microbiol 13:514-521

Gardner CL, Sun C, Luke T et al (2017) Antibody preparations from human transchromosomic cows exhibit prophylactic and therapeutic 
efficacy against venezuelan equine encephalitis virus. J Virol 91: e00226-e00217

Gaudray G, Gachon F, Basbous J et al (2002) The complementary strand of the human T-cell leukemia virus type 1 RNA genome encodes a bZIP transcription factor that down-regulates viral transcription. J Virol 76:12813-12822

Gentsch JR, Laird AR, Bielfelt B et al (2005) Serotype diversity and reassortment between human and animal rotavirus strains: implications for rotavirus vaccine programs. J Infect Dis 192:S146-S159

Gerdts V, Wilson HL, Meurens F et al (2015) Large animal models for vaccine development and testing. ILAR J 56:53-62

Gershwin LJ (2007) Bovine respiratory syncytial virus infection: immunopathogenic mechanisms. Anim Health Res Rev 8:207213. https://doi.org/10.1017/S1466252307001405

Gershwin LJ (2012) Immunology of bovine respiratory syncytial virus infection of cattle. Comp Immunol Microbiol Infect Dis 35:253257. https://doi.org/10.1016/j.cimid.2012.01.005

Gershwin LJ, Schelegle ES, Gunther RA et al (1998) A bovine model of vaccine enhanced respiratory syncytial virus pathophysiology. Vaccine 16:1225-1236

Gethmann J, Homeier T, Holsteg M et al (2015) BVD-2 outbreak leads to high losses in cattle farms in Western Germany. Heliyon 1:e00019

Gibbens JC, Wilesmith JW, Sharpe CE et al (2001) Descriptive epidemiology of the 2001 foot-and-mouth disease epidemic in Great Britain: the first five months. Vet Rec 149:729-743

Gilbert M, Mitchell A, Bourn D et al (2005) Cattle movements and bovine tuberculosis in Great Britain. Nature 435:491-496

Gillet N, Florins A, Boxus M et al (2007) Mechanisms of leukemogenesis induced by bovine leukemia virus: prospects for novel anti-retroviral therapies in human. Retrovirology 4:1-32

Gonda MA, Wong-Staal F, Gallo RC et al (1985) Sequence homology and morphologic similarity of HTLV-III and visna virus, a pathogenic lentivirus. Science 227:173-177

Gonda MA, Braun MJ, Clements JE et al (1986) Human T-cell lymphotropic virus type III shares sequence homology with a family of pathogenic lentiviruses. Proc Natl Acad Sci 83:4007-4011

Gonda MA, Braun MJ, Carter SG et al (1987) Characterization and molecular cloning of a bovine lentivirus related to human immunodeficiency virus. Nature 330:388-391

Gortázar C, Ferroglio E, Höfle U et al (2007) Diseases shared between wildlife and livestock: a European perspective. Eur J Wildl Res 53: 241

Graham BS (2016) Vaccines against respiratory syncytial virus: the time has finally come. Vaccine 34:3535-3541

Grassmann R, Dengler C, Müller-Fleckenstein I et al (1989) Transformation to continuous growth of primary human T lymphocytes by human T-cell leukemia virus type I X-region genes transduced by a Herpesvirus saimiri vector. Proc Natl Acad Sci 86:33513355

Green CA, Scarselli E, Sande CJ et al (2015) Chimpanzee adenovirusand MVA-vectored respiratory syncytial virus vaccine is safe and immunogenic in adults. Sci Transl Med 7:300ra126

Greenberg HB, Kalica AR, Wyatt RG et al (1981) Rescue of noncultivatable human rotavirus by gene reassortment during mixed infection with ts mutants of a cultivatable bovine rotavirus. Proc Natl Acad Sci 78:420-424

Greenberg DP, Yeh S, Yogev R et al (1999) Evaluation of the safety, immunogenicity and virus shedding of an intranasal live attenuated bovine parainfluenza virus type 3 vaccine in infants. Pediatr Res 45: 161

Greger M (2007) The human/animal interface: emergence and resurgence of zoonotic infectious diseases. Crit Rev Microbiol 33:243-299

Grell SN, Riber U, Tjørnehøj K et al (2005) Age-dependent differences in cytokine and antibody responses after experimental RSV infection in a bovine model. Vaccine 23:3412-3423
Grillo-López AJ, White CA, Varns C et al (1999) Overview of the clinical development of rituximab: first monoclonal antibody approved for the treatment of lymphoma. In: Seminars in oncology, pp 66-73

Guzman E, Taylor G (2015) Immunology of bovine respiratory syncytial virus in calves. Mol Immunol 66:48-56. https://doi.org/10.1016/j. molimm.2014.12.004

Haanes EJ, Guimond P, Wardley R (1997) The bovine parainfluenza virus type-3 (BPIV-3) hemagglutinin/neuraminidase glycoprotein expressed in baculovirus protects calves against experimental BPIV-3 challenge. Vaccine 15:730-738

Hall CB (2001) Respiratory syncytial virus and parainfluenza virus. N Engl J Med 344:1917-1928

Haller AA, Miller T, Mitiku M, Coelingh K (2000) Expression of the surface glycoproteins of human parainfluenza virus type 3 by bovine parainfluenza virus type 3 , a novel attenuated virus vaccine vector. $\mathrm{J}$ Virol 74:11626-11635

Haller AA, MacPhail M, Mitiku M, Tang RS (2001) A single amino acid substitution in the viral polymerase creates a temperature-sensitive and attenuated recombinant bovine parainfluenza virus type 3 . Virology 288:342-350

Haller AA, Mitiku M, MacPhail M (2003) Bovine parainfluenza virus type 3 (PIV3) expressing the respiratory syncytial virus (RSV) attachment and fusion proteins protects hamsters from challenge with human PIV3 and RSV. J Gen Virol 84:2153-2162

Hamre D, Procknow JJ (1966) A new virus isolated from the human respiratory tract. Proc Soc Exp Biol Med 121:190-193

Han C, Qiao G, Hubbert NL et al (1996) Serologic association between human papillomavirus type 16 infection and esophageal cancer in Shaanxi Province, China. J Natl Cancer Inst 88:1467-1471

Hartlage AS, Cullen JM, Kapoor A (2016) The strange, expanding world of animal hepaciviruses. Annu Rev Virol 3:53-75

Hasoksuz M, Alekseev K, Vlasova A et al (2007) Biologic, antigenic, and full-length genomic characterization of a bovine-like coronavirus isolated from a giraffe. J Virol 81:4981-4990

Haster W, Owyang C (2013) Abordagem do paciente com doença gastrointestinal. In: Med Interna Harrison, 18th edn. Artmed, Porto Alegre, pp 2402-2426

Haydon DT, Cleaveland S, Taylor LH, Laurenson MK (2002) Identifying reservoirs of infection: a conceptual and practical challenge. Emerg Infect Dis 8:1468-1473

He Z, Wlazlo AP, Kowalczyk DW et al (2000) Viral recombinant vaccines to the E6 and E7 antigens of HPV-16. Virology 270:146-161

Hein WR, Griebel PJ (2003) A road less travelled: large animal models in immunological research. Nat Rev Immunol 3:79-84

Henzler H-J, Kaiser K (1998) Avoiding viral contamination in biotechnological and pharmaceutical processes. Nat Biotechnol 16:10771079

Herbster S, Ferraro CTL, Koff NK et al (2012) HPV infection in Brazilian patients with esophageal squamous cell carcinoma: interpopulational differences, lack of correlation with surrogate markers and clinicopathological parameters. Cancer Lett 326:52-58

Hewinson RG, Vordermeier HM, Buddle BM (2003) Use of the bovine model of tuberculosis for the development of improved vaccines and diagnostics. Tuberculosis 83:119-130

Hildesheim A, Herrero R, Wacholder S et al (2007) Effect of human papillomavirus 16/18 L1 viruslike particle vaccine among young women with preexisting infection: a randomized trial. Jama 298: $743-753$

Holland RE (1990) Some infectious causes of diarrhea in young farm animals. Clin Microbiol Rev 3:345-375

Hooper JW, Brocato RL, Kwilas SA et al (2014) DNA vaccine-derived human IgG produced in transchromosomal bovines protect in lethal models of hantavirus pulmonary syndrome. Sci Transl Med 6: 264ra162

Houghton M (2009) The long and winding road leading to the identification of the hepatitis C virus. J Hepatol 51:939-948 
Huisman W, Martina BEE, Rimmelzwaan GF et al (2009) Vaccineinduced enhancement of viral infections. Vaccine 27:505-512

Hurley WL, Theil PK (2011) Perspectives on immunoglobulins in colostrum and milk. Nutrients 3:442-474

Ishiguro N, Furuoka H, Matsui T et al (1997) p53 mutation as a potential cellular factor for tumor development in enzootic bovine leukosis. Vet Immunol Immunopathol 55:351-358

Isken O, Baroth M, Grassmann CW et al (2007) Nuclear factors are involved in hepatitis C virus RNA replication. Rna 13:1675-1692

Izda V, Jeffries MA, Sawalha AH (2020) COVID-19: A review of therapeutic strategies and vaccine candidates. Clin Immunol 222: 108634

Jarrett WFH, Smith KT, O'neil BW et al (1991) Studies on vaccination against papillomaviruses: prophylactic and therapeutic vaccination with recombinant structural proteins. Virology 184:33-42

Jawhara S (2020) Can drinking microfiltered raw immune milk from cows immunized against SARS-CoV-2 provide short-term protection against COVID-19? Front Immunol 11:1888

Jensen WA, Rovnak J, Cockerell GL (1991) In vivo transcription of the bovine leukemia virus tax/rex region in normal and neoplastic lymphocytes of cattle and sheep. J Virol 65:2484-2490

Johnson JE, Gonzales RA, Olson SJ et al (2007) The histopathology of fatal untreated human respiratory syncytial virus infection. Mod Pathol 20:108-119

Jordan R, Shao M, Mackman RL et al (2015) Antiviral efficacy of a respiratory syncytial virus (RSV) fusion inhibitor in a bovine model of RSV infection. Antimicrob Agents Chemother 59:4889-4900

Kalina WV, Woolums AR, Berghaus RD, Gershwin LJ (2004) Formalininactivated bovine RSV vaccine enhances a Th2 mediated immune response in infected cattle. Vaccine 22:1465-1474

Kapikian AZ, Mitchell RH, Chanock RM et al (1969) An epidemiologic study of altered clinical reactivity to respiratory syncytial (RS) virus infection in children previously vaccinated with an inactivated RS virus vaccine. Am J Epidemiol 89:405-421

Kapoor A, Simmonds P, Gerold G et al (2011) Characterization of a canine homolog of hepatitis C virus. Proc Natl Acad Sci 108: $11608-11613$

Kasonta R, Holsteg M, Duchow K et al (2014) Colostrum from cows immunized with a vaccine associated with bovine neonatal pancytopenia contains Allo-antibodies that cross-react with human MHCI molecules. PLoS One 9:e109239

Katoh I, Yoshinaka Y, Ikawa Y (1989) Bovine leukemia virus transactivator $\mathrm{p} 38$ tax activates heterologous promoters with a common sequence known as a cAMP-responsive element or the binding site of a cellular transcription factor ATF. EMBO J 8:497-503

Kell DB, Heyden EL, Pretorius E (2020) The biology of lactoferrin, an iron-binding protein that can help defend against viruses and bacteria. Front Immunol 11:1221

Kim HW, Canchola JG, Brandt CD et al (1969) Respiratory syncytial virus disease in infants despite prior administration of antigenic inactivated vaccine. Am J Epidemiol 89:422-434. https://doi.org/ 10.1093/oxfordjournals.aje.a120955

King AMQ, Lefkowitz E, Adams MJ, Carstens EB (2011) Virus taxonomy: ninth report of the International Committee on Taxonomy of Viruses. Elsevier

Kirnbauer R, Booy F, Cheng N et al (1992) Papillomavirus L1 major capsid protein self-assembles into virus-like particles that are highly immunogenic. Proc Natl Acad Sci 89:12180-12184

Kirschvink N, Reinhold P (2008) Use of alternative animals as asthma models. Curr Drug Targets 9:470-484

Klippmark E, Rydbeck R, Shibuta H, Norrby E (1990) Antigenic variation of human and bovine parainfluenza virus type 3 strains. J Gen Virol 71:1577-1580

Knudson CJ, Hartwig SM, Meyerholz DK, Varga SM (2015) RSV vaccine-enhanced disease is orchestrated by the combined actions of distinct CD4 T cell subsets. PLoS Pathog 11:e1004757
Komoto S, Pongsuwanna Y, Tacharoenmuang R et al (2016) Whole genomic analysis of bovine group A rotavirus strains A5-10 and A5-13 provides evidence for close evolutionary relationship with human rotaviruses. Vet Microbiol 195:37-57

Koutsky LA, Ault KA, Wheeler CM et al (2002) A controlled trial of a human papillomavirus type 16 vaccine. N Engl J Med 347:16451651

Kues WA, Niemann H (2004) The contribution of farm animals to human health. Trends Biotechnol 22:286-294

Kumar P, Jangir BL, Saikumar G, Somvanshi R (2013) Co-infection of bovine papillomavirus type- 1 and-10 in teat warts of dairy cattle. Vet Med (Praha) 58:605-608

Kumar P, Nagarajan N, Saikumar G et al (2015) Detection of bovine papilloma viruses in wart-like lesions of upper gastrointestinal tract of cattle and buffaloes. Transbound Emerg Dis 62:264-271

Kuroiwa Y, Kasinathan P, Choi YJ et al (2002) Cloned transchromosomic calves producing human immunoglobulin. Nat Biotechnol 20:889-894

Lagarias DM, Radke K (1989) Transcriptional activation of bovine leukemia virus in blood cells from experimentally infected, asymptomatic sheep with latent infections. J Virol 63:2099-2107

Lagergren J, Wang Z, Bergström R et al (1999) Human papillomavirus infection and esophageal cancer: a nationwide seroepidemiologic case-control study in Sweden. J Natl Cancer Inst 91:156-162

Lairmore MD (2014) Animal models of bovine leukemia virus and human T-lymphotrophic virus type-1: insights in transmission and pathogenesis. Annu Rev Anim Biosci 2:189-208

Lanzas C, Ayscue P, Ivanek R, Gröhn YT (2010) Model or meal? Farm animal populations as models for infectious diseases of humans. Nat Rev Microbiol 8:139-148

Lau SKP, Lee P, Tsang AKL et al (2011) Molecular epidemiology of human coronavirus OC43 reveals evolution of different genotypes over time and recent emergence of a novel genotype due to natural recombination. J Virol 85:11325-11337

Lee M-S, Greenberg DP, Yeh SH et al (2001) Antibody responses to bovine parainfluenza virus type 3 (PIV3) vaccination and human PIV3 infection in young infants. J Infect Dis 184:909-913

Lee WS, Wheatley AK, Kent SJ, DeKosky BJ (2020) Antibodydependent enhancement and SARS-CoV-2 vaccines and therapies. Nat Microbiol 5:1185-1191

Leisering A (1871) Hypertrophy der Malpigischen Korperchen der Milz. Bericht Vet Konigreich Sachsen 16:15-16

Levy O (2007) Innate immunity of the newborn: basic mechanisms and clinical correlates. Nat Rev Immunol 7:379-390

Lezin A, Olindo S, Belrose G et al (2009) Gene activation therapy: from the BLV model to HAM/TSP patients. Front Biosci (Schol Ed) 1: 205

Liang TJ, Rehermann B, Seeff LB, Hoofnagle JH (2000) Pathogenesis, natural history, treatment, and prevention of hepatitis C. Ann Intern Med 132:296-305

Ling Z, Tran KC, Teng MN (2009) Human respiratory syncytial virus nonstructural protein NS2 antagonizes the activation of beta interferon transcription by interacting with RIG-I. J Virol 83:3734-3742

Liu Z, Wu H, Egland KA et al (2021) Human immunoglobulin from transchromosomic bovines hyperimmunized with SARS-CoV-2 spike antigen efficiently neutralizes viral variants. In: bioRxiv

Loss G, Depner M, Ulfman LH et al (2015) Consumption of unprocessed cow's milk protects infants from common respiratory infections. J Allergy Clin Immunol 135:56-62

Lu G, Jia K, Ping X et al (2018) Novel bovine hepacivirus in dairy cattle, China. Emerg Microbes Infect 7:1-3

Lua LHL, Connors NK, Sainsbury F et al (2014) Bioengineering viruslike particles as vaccines. Biotechnol Bioeng 111:425-440

Luke T, Wu H, Zhao J et al (2016) Human polyclonal immunoglobulin G from transchromosomic bovines inhibits MERS-CoV in vivo. Sci 
Transl Med 8:326ra21. https://doi.org/10.1126/scitranslmed. aaf1061

Lunardi M, Alfieri AA, Otonel RAA, Alfieri AF (2013) Bovine Papillomaviruses-Taxonomy and Genetic. In: Curr Issues Mol Virol Viral Genet Biotechnol Appl, p 113

Luscombe CA, Huang Z, Murray MG et al (2010) A novel Hepatitis C virus $\mathrm{p} 7$ ion channel inhibitor, BIT225, inhibits bovine viral diarrhea virus in vitro and shows synergism with recombinant interferon- $\alpha$ $2 \mathrm{~b}$ and nucleoside analogues. Antivir Res 86:144-153

Lyronis ID, Baritaki S, Bizakis I et al (2005) Evaluation of the prevalence of human papillomavirus and Epstein-Barr virus in esophageal squamous cell carcinomas. Int J Biol Markers 20:5-10

Mainer G, Sanchez L, Ena JM, Calvo M (1997) Kinetic and thermodynamic parameters for heat denaturation of bovine milk IgG, IgA and IgM. J Food Sci 62:1034-1038

Marchica V, Franceschi V, Vescovini R et al (2020) Bovine pestivirus is a new alternative virus for multiple myeloma oncolytic virotherapy. $\mathrm{J}$ Hematol Oncol 13:1-15

Marrazzo J, Holmes K (2013) Infecções sexualmente transmissívies: Consideraçoes gerais e abordagem clinica. In: Med Interna Harrison, 18th edn. Artmed, Porto Alegre, pp 1095-11111

Marshall BM, Levy SB (2011) Food animals and antimicrobials: impacts on human health. Clin Microbiol Rev 24:718-733

Martella V, Bányai K, Ciarlet M et al (2006) Relationships among porcine and human $\mathrm{P}[6]$ rotaviruses: evidence that the different human $\mathrm{P}[6]$ lineages have originated from multiple interspecies transmission events. Virology 344:509-519

Martínez-López B, Perez AM, De la Torre A, Rodriguez JMS-V (2008) Quantitative risk assessment of foot-and-mouth disease introduction into Spain via importation of live animals. Prev Vet Med 86:43-56

Marwick C (2000) FDA calls bovine-based vaccines currently safe. JAMA 284:1231-1232

Masuda EK, Kommers GD, Rosa FB et al (2011) Relação entre a linfopenia e a persistência da papilomatose alimentar em bovinos intoxicados crônica e espontaneamente por samambaia (Pteridium aquilinum). Pesqui Vet Bras 31:383-388

Matrosovich M, Herrler G, Klenk HD (2015) In: Gerardy-Schahn R, Delannoy P, von Itzstein M (eds) Sialic Acid Receptors of Viruses BT - SialoGlyco Chemistry and Biology II: Tools and Techniques to Identify and Capture Sialoglycans. Springer International Publishing, Cham, pp 1-28

Matsuoka M, Jeang K-T (2007) Human T-cell leukaemia virus type 1 (HTLV-1) infectivity and cellular transformation. Nat Rev Cancer 7: 270-280

Matthijnssens J, Rahman M, Martella V et al (2006) Full genomic analysis of human rotavirus strain B4106 and lapine rotavirus strain 30/ 96 provides evidence for interspecies transmission. J Virol 80:38013810

Matukonis M, Li M, Molina RP et al (2002) Development of second-and third-generation bovine immunodeficiency virus-based gene transfer systems. Hum Gene Ther 13:1293-1303

McCluskey BJ (2003) Use of sentinel herds in monitoring and surveillance systems. In: Anim Dis Surveill Surv Syst Methods Appl, pp $119-133$

McIntosh K, Dees JH, Becker WB et al (1967) Recovery in tracheal organ cultures of novel viruses from patients with respiratory disease. Proc Natl Acad Sci U S A 57:933

Mebus CA, Underdahl NR, Rhodes MB, Twiehaus MJ (1969) Further studies on neonatal calf diarrhea virus. In: Proceedings, annual meeting of the United States Animal Health Association, p 97

Meischke HRC (1979) In vitro transformation by bovine papilloma virus. J Gen Virol 43:473-487

Mendez E, Ruggli N, Collett MS, Rice CM (1998) Infectious bovine viral diarrhea virus (strain NADL) RNA from stable cDNA clones: a cellular insert determines NS3 production and viral cytopathogenicity. J Virol 72:4737-4745
Meyer G, Deplanche M, Schelcher F (2008) Human and bovine respiratory syncytial virus vaccine research and development. Comp Immunol Microbiol Infect Dis 31:191-225

Meyling A, Houe H, Jensen AM (1990) Epidemiology of bovine virus diarrhoea virus. Rev Sci Tech 9:75-93

Misdorp W (1996) Veterinary cancer epidemiology. Vet Q 18:32-36

Mohd Hanafiah K, Groeger J, Flaxman AD, Wiersma ST (2013) Global epidemiology of hepatitis $\mathrm{C}$ virus infection: new estimates of agespecific antibody to HCV seroprevalence. Hepatology 57:13331342

Morales-Sánchez A, Fuentes-Pananá EM (2014) Human viruses and cancer. Viruses 6:4047-4079

Morand S, McIntyre KM, Baylis M (2014) Domesticated animals and human infectious diseases of zoonotic origins: domestication time matters. Infect Genet Evol 24:76-81

Morgan MA, Copeland TD, Oroszlan S (1983) Structural and antigenic analysis of the nucleic acid-binding proteins of bovine and feline leukemia viruses. J Virol 46:177-186

Morse SS, Mazet JAK, Woolhouse M et al (2012) Prediction and prevention of the next pandemic zoonosis. Lancet 380:1956-1965

Munday JS (2014) Bovine and human papillomaviruses: a comparative review. Vet Pathol 51:1063-1075

Munday JS, Knight CG (2010) Amplification of feline sarcoid-associated papillomavirus DNA sequences from bovine skin. Vet Dermatol 21: 341-344

Murawski MR, Bowen GN, Cerny AM et al (2009) Respiratory syncytial virus activates innate immunity through Toll-like receptor 2 . J Virol 83:1492-1500. https://doi.org/10.1128/JVI.00671-08

Murphy WJ, Pevzner PA, O’Brien SJ (2004) Mammalian phylogenomics comes of age. Trends Genet 20:631-639

Nair H, Nokes DJ, Gessner BD et al (2010) Global burden of acute lower respiratory infections due to respiratory syncytial virus in young children: a systematic review and meta-analysis. Lancet 375:15451555. https://doi.org/10.1016/S0140-6736(10)60206-1

Nederend M, van Stigt AH, Jansen JHM et al (2020) Bovine igg prevents experimental infection with rsv and facilitates human t cell responses to RSV. Front Immunol 11:1071

Oda H, Kolawole AO, Mirabelli C et al (2021) Antiviral effects of bovine lactoferrin on human norovirus. Biochem Cell Biol 99:166-172

Offit PA, Hoffenberg EJ, Santos N, Gouvea V (1993) Rotavirus-specific humoral and cellular immune response after primary, symptomatic infection. J Infect Dis 167:1436-1440

Olson C, Pamukcu AM, Brobst DF et al (1959) A urinary bladder tumor induced by a bovine cutaneous papilloma agent. Cancer Res 19:779

Onuma M, Koomoto E, Furuyama $\mathrm{H}$ et al (1992) Infection and dysfunction of monocytes induced by experimental inoculation of calves with bovine immunodeficiency-like virus. JAIDS J Acquir Immune Defic Syndr 5:1009-1015

Organization WHO (2003) Global cancer rates could increase by $50 \%$ to 15 million by 2020 . In: Global cancer rates could increase by $50 \%$ to 15 million by 2020

Organization WHO (2009) Manual of rotavirus detection and characterization methods. World Health Organization

Ortiz-Pelaez A, Pfeiffer DU, Soares-Magalhaes RJ, Guitian FJ (2006) Use of social network analysis to characterize the pattern of animal movements in the initial phases of the 2001 foot and mouth disease (FMD) epidemic in the UK. Prev Vet Med 76:40-55

Ostermann C, Linde S, Siegling-Vlitakis C, Reinhold P (2014) Evaluation of pulmonary dysfunctions and acid-base imbalances induced by Chlamydia psittaci in a bovine model of respiratory infection. Multidiscip Respir Med 9:1-16

Paccaud MF, Jacquier C (1970) A respiratory syncytial virus of bovine origin. Arch Gesamte Virusforsch 30:327-342. https://doi.org/10. 1007/BF01258363 
Paeshuyse J, Leyssen P, Mabery E et al (2006) A novel, highly selective inhibitor of pestivirus replication that targets the viral RNAdependent RNA polymerase. J Virol 80:149-160

Pangty K, Singh S, Goswami R et al (2010) Detection of BPV-1 and-2 and quantification of BPV-1 by real-time PCR in cutaneous warts in cattle and buffaloes. Transbound Emerg Dis 57:185-196

Parashar UD, Hummelman EG, Bresee JS et al (2003) Global illness and deaths caused by rotavirus disease in children. Emerg Infect Dis 9: 565

Parashar UD, Gibson CJ, Bresee JS, Glass RI (2006) Rotavirus and severe childhood diarrhea. Emerg Infect Dis 12:304

Parkin DM (2006) The global health burden of infection-associated cancers in the year 2002. Int J Cancer 118:3030-3044

Pavlović D, Neville DCA, Argaud O et al (2003) The hepatitis C virus p7 protein forms an ion channel that is inhibited by long-alkyl-chain iminosugar derivatives. Proc Natl Acad Sci 100:6104-6108

Pawlotsky J (2014) New hepatitis C therapies: the toolbox, strategies, and challenges. Gastroenterology 146:1176-1192

Pearce-Duvet JMC (2006) The origin of human pathogens: evaluating the role of agriculture and domestic animals in the evolution of human disease. Biol Rev 81:369-382

Pedersen AB, Jones KE, Nunn CL, Altizer S (2007) Infectious diseases and extinction risk in wild mammals. Conserv Biol 21:1269-1279

Pennathur S, Haller AA, MacPhail M et al (2003) Evaluation of attenuation, immunogenicity and efficacy of a bovine parainfluenza virus type 3 (PIV-3) vaccine and a recombinant chimeric bovine/human PIV-3 vaccine vector in rhesus monkeys. J Gen Virol 84:3253-3261

Perach M, Hizi A (1999) Catalytic features of the recombinant reverse transcriptase of bovine leukemia virus expressed in bacteria. Virology 259:176-189

Perez-Schael I, Guntiñas MJ, Pérez M et al (1997) Efficacy of the rhesus rotavirus-based quadrivalent vaccine in infants and young children in Venezuela. N Engl J Med 337:1181-1187

Pesavento JB, Crawford SE, Estes MK, Prasad BVV (2006) Rotavirus proteins: structure and assembly. In: Reoviruses: Entry, assembly and morphogenesis. Springer, pp 189-219

Pierra C, Amador A, Benzaria S et al (2006) Synthesis and pharmacokinetics of valopicitabine (NM283), an efficient prodrug of the potent anti-HCV agent 2 '-C-methylcytidine. J Med Chem 49:6614-6620

Poiesz BJ, Ruscetti FW, Gazdar AF et al (1980a) Detection and isolation of type $\mathrm{C}$ retrovirus particles from fresh and cultured lymphocytes of a patient with cutaneous T-cell lymphoma. Proc Natl Acad Sci 77: 7415-7419

Poiesz BJ, Ruscetti FW, Mier JW et al (1980b) T-cell lines established from human T-lymphocytic neoplasias by direct response to T-cell growth factor. Proc Natl Acad Sci 77:6815-6819

Polack FP (2007) Atypical measles and enhanced respiratory syncytial virus disease (ERD) made simple. Pediatr Res 62:111-115

Pollock JM, McNair J, Welsh MD et al (2001) Immune responses in bovine tuberculosis. Tuberculosis 81:103-107

Pollock JM, Rodgers JD, Welsh MD, McNair J (2006) Pathogenesis of bovine tuberculosis: the role of experimental models of infection. Vet Microbiol 112:141-150

Poole TL, Wang C, Popp RA et al (1995) Pestivirus translation initiation occurs by internal ribosome entry. Virology 206:750-754

Popescu C-I, Callens N, Trinel D et al (2011) NS2 protein of hepatitis C virus interacts with structural and non-structural proteins towards virus assembly. PLoS Pathog 7:e1001278

Popovic M, Sarngadharan MG, Read E, Gallo RC (1984) Detection, isolation, and continuous production of cytopathic retroviruses (HTLV-III) from patients with AIDS and pre-AIDS. Science 224: 497-500

Proietti FA, Carneiro-Proietti ABF, Catalan-Soares BC, Murphy EL (2005) Global epidemiology of HTLV-I infection and associated diseases. Oncogene 24:6058-6068
Puerstinger G, Paeshuyse J, De Clercq E, Neyts J (2007) Antiviral 2, 5disubstituted imidazo [4, 5-c] pyridines: From anti-pestivirus to antihepatitis C virus activity. Bioorg Med Chem Lett 17:390-393

Pushko P, Tumpey TM, Van Hoeven N et al (2007) Evaluation of influenza virus-like particles and Novasome adjuvant as candidate vaccine for avian influenza. Vaccine 25:4283-4290

Quan F-S, Vunnava A, Compans RW, Kang S-M (2010) Virus-like particle vaccine protects against $2009 \mathrm{H} 1 \mathrm{~N} 1$ pandemic influenza virus in mice. PLoS One 5:e9161

Rector A, Van Ranst M (2013) Animal papillomaviruses. Virology 445: 213-223

Redwan E-RM (2009) Animal-derived pharmaceutical proteins. J Immunoass Immunochem 30:262-290

Reinhold P, Ostermann C, Liebler-Tenorio E et al (2012) A bovine model of respiratory Chlamydia psittaci infection: challenge dose titration. PLoS One 7:e30125

Ribeiro-Müller L, Müller M (2014) Prophylactic papillomavirus vaccines. Clin Dermatol 32:235-247

Ribot JC, Lopes N, Silva-Santos B (2020) $\gamma \delta$ T cells in tissue physiology and surveillance. Nat Rev Immunol 21:221-232

Rodrigues R, Cuddington B, Mossman K (2010) Bovine herpesvirus type 1 as a novel oncolytic virus. Cancer Gene Ther 17:344-355

Romero MR, Serrano MA, Vallejo M et al (2006) Antiviral effect of artemisinin from Artemisia annua against a model member of the Flaviviridae family, the bovine viral diarrhoea virus (BVDV). Planta Med 72:1169-1174

Roperto S, Brun R, Paolini F et al (2008) Detection of bovine papillomavirus type 2 in the peripheral blood of cattle with urinary bladder tumours: possible biological role. J Gen Virol 89:3027-3033

Roperto S, Munday JS, Corrado F et al (2016) Detection of bovine papillomavirus type 14 DNA sequences in urinary bladder tumors in cattle. Vet Microbiol 190:1-4

Roperto S, Russo V, De Falco F et al (2019) Congenital papillomavirus infection in cattle: Evidence for transplacental transmission. Vet Microbiol 230:95-100

Rosenberg HF, Domachowske JB (2012) Inflammatory responses to respiratory syncytial virus (RSV) infection and the development of immunomodulatory pharmacotherapeutics. Curr Med Chem 19: 1424-1431

Rudd BD, Burstein E, Duckett CS et al (2005) Differential role for TLR3 in respiratory syncytial virus-induced chemokine expression. J Virol 79:3350-3357. https://doi.org/10.1128/JVI.79.6.3350-3357.2005

Russo V, Roperto F, Esposito I et al (2016) ERas protein is overexpressed and binds to the activated platelet-derived growth factor $\beta$ receptor in bovine urothelial tumour cells associated with papillomavirus infection. Vet J 212:44-47

Ruuskanen O, Ogra PL (1993) Respiratory syncytial virus. Curr Probl Pediatr 23:50-79

Sacco RE, Nonnecke BJ, Palmer MV et al (2012) Differential expression of cytokines in response to respiratory syncytial virus infection of calves with high or low circulating 25-hydroxyvitamin D3. PLoS One 7:e33074. https://doi.org/10.1371/journal.pone.0033074

Sagata N, Yasunaga T, Ohishi K et al (1984) Comparison of the entire genomes of bovine leukemia virus and human $\mathrm{T}$-cell leukemia virus and characterization of their unidentified open reading frames. EMBO J 3:3231-3237

Saied AA, Metwally AA (2019) Bovine-Origin Human Therapy; Need More Attention. Int J Curr Microbiol App Sci 8:2766-2770. https:// doi.org/10.20546/ijcmas.2019.809.318

Saif LJ (1990) Comparative aspects of enteric viral infections. Viral Diarrh Man Anim 473:9-31

Saif LJ, Jung K (2020) Comparative pathogenesis of bovine and porcine respiratory coronaviruses in the animal host species and SARSCoV-2 in humans. J Clin Microbiol 58:e01355-e01320

Saif LJ, Wang Q, Vlasova AN et al (2019) Coronaviruses. Dis Swine 19: 488-523 
Sakai A, Claire MS, Faulk K et al (2003) The p7 polypeptide of hepatitis $\mathrm{C}$ virus is critical for infectivity and contains functionally important genotype-specific sequences. Proc Natl Acad Sci 100:11646-11651

Saminathan M, Singh KP, Rajasekar R et al (2019) Role of type I interferons in the pathogenesis of bluetongue virus in mice and ruminants. J Exp Biol Agric Sci 7:513-520

Scheel TKH, Simmonds P, Kapoor A (2015) Surveying the global virome: identification and characterization of HCV-related animal hepaciviruses. Antivir Res 115:83-93

Schiller JT, Day PM, Kines RC (2010) Current understanding of the mechanism of HPV infection. Gynecol Oncol 118:S12-S17

Schlender J, Bossert B, Buchholz U, Conzelmann K-K (2000) Bovine respiratory syncytial virus nonstructural proteins NS1 and NS2 cooperatively antagonize alpha/beta interferon-induced antiviral response. J Virol 74:8234-8242

Schultz RD, Dunne HW, Heist CE (1973) Ontogeny of the bovine immune response. Infect Immun 7:981-991

Sharun K, Dhama K, Pawde AM et al (2021) SARS-CoV-2 in animals: potential for unknown reservoir hosts and public health implications. Vet Q 41:1-31

Siegrist CA (2001) Neonatal and early life vaccinology. Vaccine 19: 3331-3346. https://doi.org/10.1016/s0264-410x(01)00028-7

Simons BW, Cannella F, Rowley DT, Viscidi RP (2020) Bovine papillomavirus prostate cancer antigen virus-like particle vaccines are efficacious in advanced cancers in the TRAMP mouse spontaneous prostate cancer model. Cancer Immunol Immunother 69:641-651

Snowder GD, Van Vleck LD, Cundiff LV, Bennett GL (2006) Bovine respiratory disease in feedlot cattle: environmental, genetic, and economic factors. J Anim Sci 84:1999-2008

Sok D, Le KM, Vadnais M et al (2017) Rapid elicitation of broadly neutralizing antibodies to HIV by immunization in cows. Nature 548:108-111

Srikumaran S, Kelling CL, Ambagala A (2007) Immune evasion by pathogens of bovine respiratory disease complex. Anim Health Res Rev $8: 215$

Stott EJ, Taylor G (1985) Respiratory syncytial virus. Arch Virol 84:1-52

Suarez DL, VanDerMaaten MJ, Wood C, Whetstone CA (1993) Isolation and characterization of new wild-type isolates of bovine lentivirus. J Virol 67:5051-5055

Syrjänen KJ (1982) Histological changes identical to those of condylomatous lesions found in esophageal squamous cell carcinomas. Arch Geschwulstforsch 52:283-292

Syrjänen KJ (2002) HPV infections and oesophageal cancer. J Clin Pathol 55:721-728

Tajima S, Aida Y (2000) The region between amino acids 245 and 265 of the bovine leukemia virus (BLV) tax protein restricts transactivation not only via the BLV enhancer but also via other retrovirus enhancers. J Virol 74:10939-10949

Tajima S, Zhuang WZ, Kato MV et al (1998) Function and conformation of wild-type $\mathrm{p} 53$ protein are influenced by mutations in bovine leukemia virus-induced B-cell lymphosarcoma. Virology 243:235-246

Tanaka A, Takahashi C, Yamaoka S et al (1990) Oncogenic transformation by the tax gene of human T-cell leukemia virus type I in vitro. Proc Natl Acad Sci 87:1071-1075

Taylor G (2013) Bovine model of respiratory syncytial virus infection. In: Challenges and opportunities for respiratory syncytial virus vaccines. Springer, pp 327-345

Taylor G, Wyld S, Valarcher J-F et al (2014) Recombinant bovine respiratory syncytial virus with deletion of the $\mathrm{SH}$ gene induces increased apoptosis and pro-inflammatory cytokines in vitro, and is attenuated and induces protective immunity in calves. J Gen Virol 95:1244 1254. https://doi.org/10.1099/vir.0.064931-0

Taylor G, Thom M, Capone S et al (2015) Efficacy of a virus-vectored vaccine against human and bovine respiratory syncytial virus infections. Sci Transl Med 7:300ra127
Teifke JP, Kidney BA, Löhr CV, Yager JA (2003) Detection of papillomavirus-DNA in mesenchymal tumour cells and not in the hyperplastic epithelium of feline sarcoids. Vet Dermatol 14:47-56

Thomas LH, Stott EJ, Collins AP et al (1984) Infection of gnotobiotic calves with a bovine and human isolate of respiratory syncytial virus. Modification of the response by dexamethasone. Arch Virol 79:67-77. https://doi.org/10.1007/BF01314304

Tian L, Qiang T, Liang C et al (2021) RNA-dependent RNA polymerase (RdRp) inhibitors: The current landscape and repurposing for the COVID-19 pandemic. Eur J Med Chem 213:113201

Tiwari R, Dhama K, Sharun K et al (2020) COVID-19: animals, veterinary and zoonotic links. Vet Q 40:169-182

Tolstov Y, Hadaschik B, Pahernik S et al (2014) Human papillomaviruses in urological malignancies: a critical assessment. In: Urologic Oncology: Seminars and Original Investigations. Elsevier, pp 46e19

Tretyakova I, Hidajat R, Hamilton G et al (2016) Preparation of quadrisubtype influenza virus-like particles using bovine immunodeficiency virus gag protein. Virology 487:163-171

Tseng C-T, Sbrana E, Iwata-Yoshikawa N et al (2012) Immunization with SARS coronavirus vaccines leads to pulmonary immunopathology on challenge with the SARS virus. PLoS One 7:e35421

Ulfman LH, Leusen JHW, Savelkoul HFJ et al (2018) Effects of bovine immunoglobulins on immune function, allergy, and infection. Front Nutr 5:52

Valarcher J-F, Taylor G (2007) Bovine respiratory syncytial virus infection. Vet Res 38:153-180. https://doi.org/10.1051/vetres:2006053

Van Der Hoek L, Pyrc K, Jebbink MF et al (2004) Identification of a new human coronavirus. Nat Med 10:368-373

Van Der Maaten MJ, Boothe AD, Seger CL (1972) Isolation of a virus from cattle with persistent lymphocytosis. J Natl Cancer Inst 49: $1649-1657$

Van der Poel WHM, Brand A, Kramps JA, Van Oirschot JT (1994) Respiratory syncytial virus infections in human beings and in cattle. J Inf Secur 29:215-228

Van Doorslaer K (2013) Evolution of the papillomaviridae. Virology 445:11-20

Van Dyk E, Bosman A-M, Van Wilpe E et al (2011) Detection and characterisation of papillomavirus in skin lesions of giraffe and sable antelope in South Africa. J S Afr Vet Assoc 82:80-85

van Wyke Coelingh KL, Winter CC, Tierney EL et al (1988) Attenuation of bovine parainfluenza virus type 3 in nonhuman primates and its ability to confer immunity to human parainfluenza virus type 3 challenge. J Infect Dis 157:655-662

Vandepapelière P, Barrasso R, Meijer CJLM et al (2005) Randomized controlled trial of an adjuvanted human papillomavirus (HPV) type 6 L2E7 vaccine: infection of external anogenital warts with multiple HPV types and failure of therapeutic vaccination. J Infect Dis 192: 2099-2107

Vemuri HS, Challa S, Neelapu NRR (2020) Evolution, Distribution, and Diversity of Immunodeficiency Viruses BT - Dynamics of Immune Activation in Viral Diseases. In: Bramhachari PV (ed) . Springer Singapore, Singapore, pp 187-203

Vesikari T, Clark HF, Offit PA et al (2006) Effects of the potency and composition of the multivalent human-bovine (WC3) reassortant rotavirus vaccine on efficacy, safety and immunogenicity in healthy infants. Vaccine 24:4821-4829

Vieira CL, Lopes JC, Velosa J (2013) A case of esophageal squamous cell carcinoma with positive HPV 11. Gastroenterol Hepatol 36: $311-315$

Vijgen L, Keyaerts E, Moës E et al (2005) Complete genomic sequence of human coronavirus OC43: molecular clock analysis suggests a relatively recent zoonotic coronavirus transmission event. J Virol 79:1595-1604

Vijgen L, Keyaerts E, Lemey P et al (2006) Evolutionary history of the closely related group 2 coronaviruses: porcine hemagglutinating 
encephalomyelitis virus, bovine coronavirus, and human coronavirus OC43. J Virol 80:7270-7274

Viuff B, Uttenthal A, Tegtmeier C, Alexandersen S (1996) Sites of replication of bovine respiratory syncytial virus in naturally infected calves as determined by in situ hybridization. Vet Pathol 33:383390

Vlasak R, Luytjes W, Spaan W, Palese P (1988) Human and bovine coronaviruses recognize sialic acid-containing receptors similar to those of influenza C viruses. Proc Natl Acad Sci 85:4526-4529

Walker LM, Burton DR (2018) Passive immunotherapy of viral infections:'super-antibodies' enter the fray. Nat Rev Immunol 18:297

Wang H, Machesky NJ, Mansky LM (2004) Both the PPPY and PTAP motifs are involved in human T-cell leukemia virus type 1 particle release. J Virol 78:1503-1512

Watanabe T (2011) Current status of HTLV-1 infection. Int J Hematol 94: 430-434

Waters WR, Palmer MV, Buddle BM, Vordermeier HM (2012) Bovine tuberculosis vaccine research: historical perspectives and recent advances. Vaccine 30:2611-2622

Weingartl H, Czub M, Czub S et al (2004) Immunization with modified vaccinia virus Ankara-based recombinant vaccine against severe acute respiratory syndrome is associated with enhanced hepatitis in ferrets. J Virol 78:12672-12676

Weiskircher E, Aligo J, Ning G, Konan KV (2009) Bovine viral diarrhea virus NS4B protein is an integral membrane protein associated with Golgi markers and rearranged host membranes. Virol J 6:1-15

Welliver RC, Wong DT, Sun M, McCarthy N (1986) Parainfluenza virus bronchiolitis: epidemiology and pathogenesis. Am J Dis Child 140: 34-40

Welliver TP, Reed JL, Welliver RC Sr (2008) Respiratory syncytial virus and influenza virus infections: observations from tissues of fatal infant cases. Pediatr Infect Dis J 27:S92-S96

Werling D, Collins RA, Taylor G, Howard CJ (2002) Cytokine responses of bovine dendritic cells and $\mathrm{T}$ cells following exposure to live or inactivated bovine respiratory syncytial virus. J Leukoc Biol 72: 297-304

Whetstone CA, VanDerMaaten MJ, Black JW (1990) Humoral immune response to the bovine immunodeficiency-like virus in experimentally and naturally infected cattle. J Virol 64:3557-3561

WHO (2021). WHO COVID-19 Dashboard - Up to date data on pandemic. https://covid19.who.int/?gclid= CjwKCAiApNSABhAlEiwANuR9YM0k0JigJ56NivXbxLoG NuUC2W0j79EBV9ZLho5WBFDR7AO8Bt2ihoCqfoQAvD_ BwE Accessed on May 10, 2021.

Wiles S, Hanage WP, Frankel G, Robertson B (2006) Modelling infectious disease - time to think outside the box? Nat Rev Microbiol 4: 307-312

Willcocks S, Offord V, Seyfert H-M et al (2013) Species-specific PAMP recognition by TLR 2 and evidence for species-restricted interaction with Dectin-1. J Leukoc Biol 94:449-458. https://doi.org/10.1189/ jlb.0812390

Willems L, Heremans H, Chen G et al (1990) Cooperation between bovine leukaemia virus transactivator protein and Ha-ras oncogene product in cellular transformation. EMBO J 9:1577-1581

Woo PCY, Lau SKP, Chu C et al (2005) Characterization and complete genome sequence of a novel coronavirus, coronavirus HKU1, from patients with pneumonia. J Virol 79:884-895

Wood PR, Corner LA, Plackett P (1990) Development of a simple, rapid in vitro cellular assay for bovine tuberculosis based on the production of $\gamma$ interferon. Res Vet Sci 49:46-49

Woolhouse M, Gaunt E (2007) Ecological origins of novel human pathogens. Crit Rev Microbiol 33:231-242

Woolhouse MEJ, Gowtage-Sequeria S (2005) Host range and emerging and reemerging pathogens. Emerg Infect Dis 11:1842
Woolley SA, Tsimnadis ER, Lenghaus C et al (2020) Molecular basis for a new bovine model of Niemann-Pick type C disease. PLoS One 15: e0238697

Wosiacki SR, Claus MP, Alfieri AF, Alfieri AA (2006) Bovine papillomavirus type 2 detection in the urinary bladder of cattle with chronic enzootic haematuria. Mem Inst Oswaldo Cruz 101:635-638

Wu F, Zhao S, Yu B et al (2020) A new coronavirus associated with human respiratory disease in China. Nature 579:265-269

Yanagida K, Baba C, Baba M (2004) Inhibition of bovine viral diarrhea virus (BVDV) by mizoribine: synergistic effect of combination with interferon- $\alpha$. Antivir Res 64:195-201

Yao Y, Huang W, Yang X et al (2013) HPV-16 E6 and E7 protein T cell epitopes prediction analysis based on distributions of HLA-A loci across populations: an in silico approach. Vaccine 31:2289-2294

Yusuf S, Piedimonte G, Auais A et al (2007) The relationship of meteorological conditions to the epidemic activity of respiratory syncytial virus. Epidemiol Infect 135:1077-1090

Zaki AM, Van Boheemen S, Bestebroer TM et al (2012) Isolation of a novel coronavirus from a man with pneumonia in Saudi Arabia. N Engl J Med 367:1814-1820

Zandomeni RO, Carrera-Zandomeni M, Esteban E, Ferrer JF (1991) The trans-activating C-type retroviruses share a distinct epitope (s) that induces antibodies in certain infected hosts. J Gen Virol 72:21132119

Zhang S, Wood C, Xue W et al (1997) Immune suppression in calves with bovine immunodeficiency virus. Clin Diagn Lab Immunol 4: 232-235

Zhang X, Hasoksuz M, Spiro D et al (2007) Quasispecies of bovine enteric and respiratory coronaviruses based on complete genome sequences and genetic changes after tissue culture adaptation. Virology 363:1-10

Zhang N, Liu Z, Han Q et al (2010) Xanthohumol enhances antiviral effect of interferon $\alpha-2 b$ against bovine viral diarrhea virus, a surrogate of hepatitis $\mathrm{C}$ virus. Phytomedicine 17:310-316

Zhang R, Tang C, Guo H et al (2018) A novel glycosylated anti-CD20 monoclonal antibody from transgenic cattle. Sci Rep 8:1-11

Zhou J, Sun XY, Stenzel DJ, Frazer IH (1991) Expression of vaccinia recombinant HPV $16 \mathrm{~L} 1$ and L2 ORF proteins in epithelial cells is sufficient for assembly of HPV virion-like particles. Virology 185: 251-257

Zhou Y, Yang Y, Huang J et al (2019) Advances in MERS-CoV vaccines and therapeutics based on the receptor-binding domain. Viruses 11: 60

Zhou P, Yang X-L, Wang X-G et al (2020) A pneumonia outbreak associated with a new coronavirus of probable bat origin. Nature 579: 270-273

Zhuang W, Tajima S, Okada K et al (1997) Point mutation of p53 tumor suppressor gene in bovine leukemia virus-induced lymphosarcoma. Leukemia 3:344-346

Zimin AV, Delcher AL, Florea L et al (2009) A whole-genome assembly of the domestic cow, Bos taurus. Genome Biol 10:1-10

Zitzmann N, Mehta AS, Carrouée S et al (1999) Imino sugars inhibit the formation and secretion of bovine viral diarrhea virus, a pestivirus model of hepatitis $\mathrm{C}$ virus: implications for the development of broad spectrum anti-hepatitis virus agents. Proc Natl Acad Sci 96: $11878-11882$

Zur Hausen H (2009) The search for infectious causes of human cancers: where and why. Virology 392:1-10

Zur Hausen H, de Villiers E-M, Gissmann L (1981) Papillomavirus infections and human genital cancer. Gynecol Oncol 12:S124-S128

Publisher's note Springer Nature remains neutral with regard to jurisdictional claims in published maps and institutional affiliations. 